\title{
Caskets of Silver and Ivory from Diverse Parts of the World: Strategic Collecting for an Iberian Treasury
}

\author{
Therese Martin
}

\begin{abstract}
By focusing on San Isidoro de León in the central Middle Ages, this study investigates the multiple meanings behind the presence of objects from other cultures in a royalmonastic treasury, suggesting a reconsideration of the paths by which such pieces arrived. The development of the Isidoran collection is reexamined through a close analysis of a charter recording the 1063 donation together with early thirteenth-century writings by Lucas of Tuy. Documentary evidence is further weighed against visual analysis and technical studies of several key pieces from the medieval collection. In particular, the Beatitudes Casket (now at the Museo Arqueológico Nacional, Madrid) is singled out to demonstrate how art historical, epigraphic, and historical research come together with carbon-14 testing, revealing that the object was assembled in a very different moment from those traditionally assumed.
\end{abstract}

\section{Keywords}

treasury - San Isidoro de Leon - 1063 donation - Lucas of Tuy - royal patronage visual evidence - technical analysis

\section{Introduction}

The treasury at San Isidoro de León, with its remarkable range of high-quality objects and its various written sources, functions in the present study as a point of departure to examine larger questions about the evolution of sumptuary collections through networks of contact within and beyond Iberia during the central Middle Ages. ${ }^{1}$ In particular, this study presents a test case for reading

1 Funding for the research that led to the special issue of Medieval Encounters was provided by The Medieval Treasury across Frontiers and Generations: The Kingdom of León-Castilla in the

(C) THERESE MARTIN, 2020 | DOI:10.1163/9789004424593_003

This is an open access chapter distributed under the terms of the CC BY-NC-ND 4.0̄lierense. Martin - 9789004424593 
evidence over time, weighing the sometimes contradictory conclusions from documentary or visual sources against scientific analysis. It further addresses the geographically charged nature of objects and it identifies elite women as vectors of cultural exchange through their multiple roles as "makers of art."

I argue that the creation of a medieval treasury offers a material witness through which the interests and aspirations of those who established it are revealed. They represent "progressive accumulated histories," in the felicitous phrasing of Cecily Hilsdale. ${ }^{3}$ As is well established, luxury objects with great intrinsic value became even more prized by Christian owners, once turned to a sacred use. Beyond pious donations to a favored foundation, however, treasuries could also function as a source of gifts for allies, which bound them with reciprocal obligations, or as prestigious possessions for the owner's ostentation before an elite audience. ${ }^{4}$ Pieces made of precious metals also served to store wealth in the form of silver and gold until the need for liquidity arose. Chronicles, charters, and hagiographies recount the changing circumstances of golden caskets, precious gems, and silk textiles, making clear the importance of material culture not only for elite self-presentation, but also for the economy of the powerful.

Context of Muslim-Christian Interchange, c. 1050-1200 (PI, Therese Martin, Spanish Ministry of Economy and Competitivity, HAR2015-68614-P), which allowed members of the team to work together in León, Madrid, and New York. Thanks also are due to the Princeton Institute for International and Regional Studies at Princeton University for hosting our 2017 conference "The Medieval Iberian Treasury in the Context of Muslim-Christian Interchange." In addition to the contributors to this issue, speakers at the conference included Jerrilynn Dodds, Amanda Dotseth, Maribel Fierro, Eva Hoffman, Beatrice Kitzinger, Eduardo Manzano, and Ittai Weinryb. In 2017-2018, aspects of my research were presented at the Museo Arqueológico Nacional, Stanford University, UCLA, Southern Methodist University, and the Medieval Academy of America, allowing me to hone my arguments. While heartfelt thanks go to all team members, I am especially grateful for the critical readings offered by Amanda Dotseth, Jitske Jasperse, and Pamela Patton. Finally, the comments of Cecily Hilsdale, Kate Dimitrova, and the Medieval Encounters anonymous reviewer greatly improved this article.

2 "Makers" refers to women's multiple roles as "patrons and facilitators, producers and artists, owners and recipients;" see Therese Martin, "Exceptions and Assumptions: Women in Medieval Art History," in Reassessing the Roles of Women as "Makers" of Medieval Art and Architecture, ed. Therese Martin (Leiden: Brill, 2012), I:1-33, esp. 5 .

3 Personal communication, March 2018. Along these lines, see recently Cecily Hilsdale, "Translatio and Objecthood: The Cultural Agendas of Two Greek Manuscripts at Saint-Denis," Gesta 56/2 (2017): 151-178.

4 Two useful essays on this topic appear in Conrad Rudolph, ed., A Companion to Medieval Art: Romanesque and Gothic in Northern Europe (Malden, MA and Oxford: Blackwell Publishing, 2006): Pierre Alain Mariaux, "Collecting (and Display)," 213-232, and Brigitte Buettner, "Toward a Historiography of the Sumptuous Arts," 466-487. 
Medieval treasuries from the Iberian Peninsula are little known outside a specialized audience nor do they often survive in situ. For other lands, there is an extensive bibliography on the medieval treasuries of France, Germany, Italy, and England. ${ }^{5}$ The royal treasury of Saint-Denis outside Paris, for example, was able to be recreated for an exhibition based on the engravings that had been made before the dispersal of the pieces during the French Revolution. ${ }^{6}$ Iberian collections prior to the late Middle Ages, however, have not received the same level of scholarly attention. ${ }^{7}$ Yet the rich survivals from a royal treasury like San Isidoro de León ${ }^{8}$ offer a most uncommon set of circumstances

5 On the topic of treasuries outside the Iberian Peninsula, excellent work has been done in recent years by Pierre Alain Mariaux, "Trésor et collection. Le sort des 'curiosités naturelles' dans les trésors d'église au Moyen Âge," in Le trésor au Moyen Âge. Questions et perspectives de recherche (Neuchâtel: Institut d'Histoire de l'art et de Muséologie, 2005), 27-56; Lucas Burkart et al., eds., Le trésor au Moyen Âge. Discours, pratiques et objets (Micrologus' Library, 32) (Florence: Edizioni del Galluzzo), 2010; Cynthia Hahn, "Relics and Reliquaries: The Construction of Imperial Memory and Meaning, with Particular Attention to Treasuries at Conques, Aachen, and Quedlinburg," in Representing History, 900-1300: Art, Music, and History, ed. Robert Maxwell (University Park, PA: Pennsylvania State University Press, 2010), 133-147, 235-238; Ulrike Wendland, ed., “... das Heilige sichtbar machen." Domschätze in Vergangenheit, Gegenwart und Zukunft (Regensburg: Schnell \& Steiner, 2010); Joseph Salvatore Ackley, "Re-approaching the Western Medieval Church Treasury Inventory, c. 800-1250," Journal of Art Historiography 11 (2014): 1-37.

6 Le trésor de Saint-Denis: Musée du Louvre, Paris, 12 mars-17 juin 1991, ed. Danielle GaboritChopin (Paris: Bibliothèque Nationale; Réunion des Musées Nationaux, 1991), drawing on Michel Félibien, Histoire de l'abbaye royale de Saint-Denys en France ... (Paris: Leonard, 1706). The fundamental study of the treasury is Blaise de Montesquiou-Fezensac, Le trésor de SaintDenis, 3 vols. (Paris: Picard, 1973-77). For the early modern inventory, see Erik Inglis, "Expertise, Artifacts, and Time in the 1534 Inventory of the St-Denis Treasury," Art Bulletin 98/1 (2016): 14-42.

7 Scholarly focus for the early and central Middle Ages tends to be on selected sumptuary goods rather than on treasuries. See the studies in Splendor. Artes suntuarias en la Edad Media hispánica, ed. Laura Rodríguez Peinado, Anales de Historia del Arte, no. esp. 24 (2014), especially the introductory essay by Francisco de Asís García García, "Una nueva mirada al arte suntuario medieval hispánico," 17-26. See also Joan Duran-Porta, "L’orfebreria romànica a Catalunya (950-1250)," PhD diss., Universitat Autònoma de Barcelona, 2015.

8 Julio Pérez Llamazares, El tesoro de la Real Colegiata de San Isidoro de León (reliquias, relicarios y joyas artísticas) (León: Imprenta y Librería Religiosa, 1925). Ángela Franco Mata carried out pioneering work on the treasury of San Isidoro; see especially, "El tesoro de San Isidoro y la monarquía leonesa," Boletín del Museo Arqueológico Nacional 9 (1991): 35-68, and more recently, "Tesoros de Oviedo y León. Problemas estilísticos, liturgia e iconografía," Boletín del Museo Arqueológico Nacional 27-28 (2009-2010): 51-118. See also Etelvina Fernández González, "Imagen, devoción y suntuosidad en las aportaciones de Fernando I y Sancha al tesoro de San Isidoro de León," in Monasterios y monarcas: fundación, presencia y memoria regia en monasterios hispanos, ed. José Ángel García de Cortázar and Ramón Teja (Aguilar de Campoo: Centro de Estudios del Románico, 2012), 161-197. 
for collaborative research, filling a gap left by the lack of early modern visual evidence for Spanish treasuries of the type available for other significant collections. At San Isidoro, the material reality of ivories, textiles, and metalwork can only be fully comprehended if they are analyzed in tandem with the documents, chronicles, and miracles that make reference to treasured items: all must be scrutinized together and their value as evidence weighed one against the other. Such a range of evidence demands rigorous attention and close collaboration by specialists from different areas of study. By digging deeply into one major Iberian treasury, our findings shine a new light on the larger matter of royal-ecclesiastical holdings, demonstrating that, across this broadly medieval phenomenon, material priorities can be identified in collections beyond the oft-cited examples of Saint-Denis or the Guelph treasure. ${ }^{9}$ As a whole, this volume, dedicated to The Medieval Iberian Treasury in the Context of Cultural Interchange, offers a way into the meaningful re-use and repurposing of luxury goods, both within and across medieval cultures.

At the heart of the research project that gave rise to this volume are the works that were once gathered together at the treasury of San Isidoro de León. ${ }^{10}$ No complete catalogue has ever been published of the thirty-some pieces, created between the late tenth century and the turn of the thirteenth, that are still in situ in the Museo de la Real Colegiata de San Isidoro-many of which are all but unstudied - much less one that includes the six pieces at the Museo Arqueológico Nacional in Madrid, plus another half dozen works held by museums in Paris, St. Petersburg, and New York, among others; this task will be undertaken by my research group in the coming years as our investigations continue. For the San Isidoro treasury during the central Middle Ages, I use

$9 \quad$ On the Guelph treasure, see Der Welfenschatz: der Reliquienschatz des Braunschweiger Domes aus dem Besitze des herzoglichen Hauses Braunschweig-Lüneburg, ed. Otto von Falke, Robert Schmidt, and Georg Swarzenski (Frankfurt am Main: Frankfurter Verlagsanstalt, 1930); Dietrich Kötzsche, "Der Welfenschatz," in Heinrich der Löwe und seine Zeit: Herrschaft und Repräsentation der Welfen 1125-1235, 3 vols., ed. Jochen Luckhardt and Frank Niehoff (Munich: Hirmer Verlag, 1995), 2:511-528; Der Welfenschatz und sein Umkreis, ed. Joachim Ehlers and Dietrich Kötzsche (Mainz am Rhein: von Zabern, 1998).

10 Deep gratitude is owed to the staff of the Museo de la Real Colegiata de San Isidoro de León under the direction of Luis García Gutiérrez and Raquel Jaén, and to the Museo Arqueológico Nacional, particularly to Sergio Vidal, head of the medieval department, along with Isabel Arias. Both institutions generously facilitated first-hand access, allowing team members to examine and photograph the objects and to carry out technical analyses over the course of several campaigns, without which this research project would have been impossible. I am also grateful to the Museo de León, Museo de la Catedral de León, Museo de la Catedral de Astorga, Metropolitan Museum of Art, Cooper Hewitt Smithsonian Design Museum, and Glencairn Museum. 
the word 'collection' consciously, if cautiously, arguing that it is not primarily a random accumulation of precious objects, but instead that many of the pieces reflect a mind (or minds) at work, deliberately bringing together works from distant lands. This study, therefore, investigates the meanings behind the presence in a Leonese treasury of artifacts from other cultures, suggesting a reconsideration of the paths by which they arrived, marriage among them. The prominent place of women in the development of this collection is reexamined as I scrutinize the charter recording the 1063 donation by the rulers of León-Castilla, Fernando (r. 1037-1065) and Sancha (d. 1067), together with the early thirteenth-century writings by Lucas of Tuy. Finally, I single out for close analysis one key work to represent the larger investigation currently underway, showing how art historical, epigraphic, and historical research come together with technical analysis to reveal that the Beatitudes Casket was assembled at a moment far in time from those traditionally assumed. This object exemplifies how medieval works of art, and thus treasuries writ large, change over time to accommodate the shifting needs of their owners. By subjecting a representative piece to close visual and documentary analysis in light of technical findings, the present study tells the larger story of medieval treasuries, showing how objects themselves serve as evidence alongside — and sometimes in opposition to-archival sources.

\section{$2 \quad$ Objects from Distant Lands}

If San Isidoro's treasury is known to scholars outside specialist circles, it is for the plethora of sumptuous ivory pieces from a range of origins and for the uncommonly diverse nature of its collection, including Andalusi and Fatimid metalworks, silks from Byzantium and farther east, caskets newly made in Limoges or of unknown provenance, others repurposed, and much more.11 Among them, and unique in the Iberian Peninsula, is a small antler container of Scandinavian manufacture (Figures 2.1a, 2.1b; no. IIC-3-089-002-0oog). According to James Graham-Campbell, it can be dated on stylistic grounds between the 96os and ca. 1000/1025 (Mammen style). ${ }^{12}$ The original function

11 A number of objects from San Isidoro's treasury figure prominently in three major exhibition catalogues: Jerrilynn D. Dodds, ed., Al-Andalus, The Art of Islamic Spain (New York: Metropolitan Museum of Art, 1992); The Art of Medieval Spain, AD 500-1200 (New York: Metropolitan Museum of Art, 1993); Isidro Bango Torviso, ed., Maravillas de la España medieval. Tesoro sagrado y monarquía (Valladolid: Junta de Castilla y León, 2001).

12 James Graham-Campbell, Viking Art (London: Thames and Hudson, 2013), 114-115. As the author rightly points out, this object should be displayed and photographed with the 

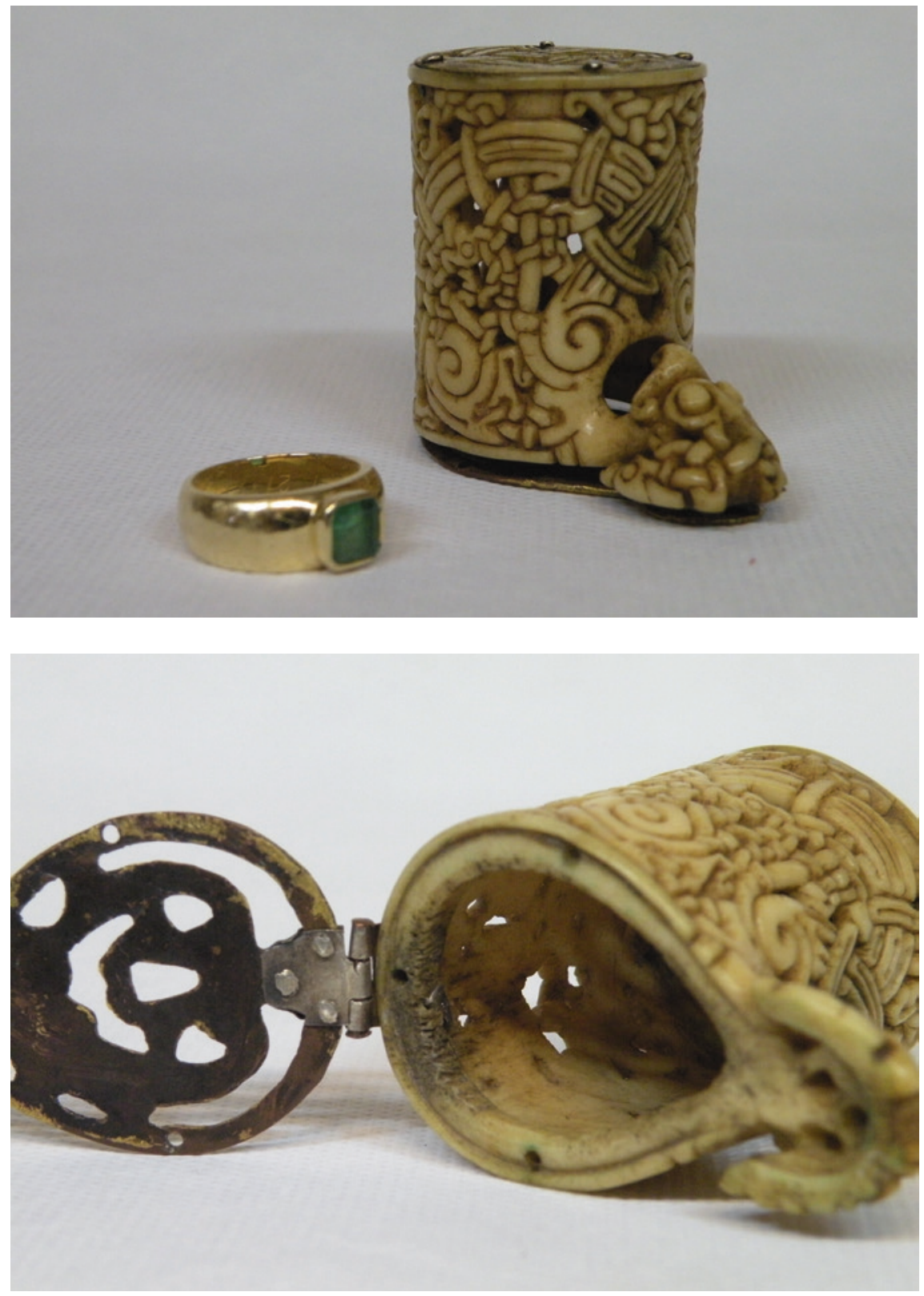

FIGURES 2.1A, B Scandinavian container for perfume (?), antler, Mammen style, ca. 960-100o/ 1025 [NB: the projecting element represents the bird's head, but the object is displayed upside down for reasons of stability; ring included for scale] (Museo de la Real Colegiata de San Isidoro de León, Inv. No. IIC-3-089-0o2-ooog). See also Figs. 9.2, 9.5, 9.6.

PHOTOS: THERESE MARTIN 
of this object is not known. Because its pierced design was thought to offer a view of its contents, most scholars assume that it was originally used as a reliquary, which was indeed its later function at San Isidoro. First-hand access to the diminutive piece, however, makes it clear that the openings worked into the intertwined design of bird and snakes are too small to allow for sight. However, what the holes would have permitted to pass through are scents. I suggest that this tiny container, only $4.4 \mathrm{~cm}$ high, was designed with an expensive solid perfume in mind. When held in the hand, where it fits comfortably, the antler would have warmed to the touch and released more odor. ${ }^{13}$ A similar function has been recognized for the ivories associated with the caliphal court in late tenth-century Córdoba. ${ }^{14}$ Exquisitely carved, the Scandinavian object in León gives evidence of elite, long-distance contacts, likely through gift or trade. ${ }^{15}$

Non-adversarial avenues of acquisition for objects from other cultures are rarely taken as a starting point in the study of works of Islamic manufacture that end up in Christian settings. Rather, scholarship has tended to give more attention to ideas of conquest and appropriation, of one religion's dominance over the other. No doubt that sense must have existed for certain objects in specific circumstances, but perhaps not as frequently as we assume, especially given the extensive system of commerce throughout the Mediterranean and beyond. In two fundamental articles published in 1995, Julie Harris says of Islamic works in Christian hands that "it is nearly certain that such pieces

protruding element—a bird's head — at the top. Instead, the larger end is used as a base to contribute to the piece's stability and safekeeping. A recent master's thesis finds connections as well to the Ringerike style (ca. 1000-ca. 1050); see Rebeca Franco Valle, "Viking Art in the Church: A Scandinavian Casket in San Isidoro de León, Spain," unpublished MPhil thesis, University of Oslo, 2016. My thanks go to the author for sending me a copy of her work.

13 In a May 2017 personal communication, Nancy Wicker agreed with my suggestion that the container was likely designed to hold a solid perfume; I am grateful to her for discussing this piece with me. See Nancy L. Wicker, "The Scandinavian Container at San Isidoro, León, in the Context of Viking Art and Society," Journal of Medieval Iberian Studies 11/2 (2019): 135-156, republished in the present volume. On the choice of permeable materials like ivory to hold incense and perfumes, see especially Lawrence Nees, "Lodorat fait-il sens? Quelque réflexions autour de l'encens de l'Antiquité tardive au haut Moyen Âge," Cahiers de Civilisation Médiévale 55 (2012): 451-471.

14 On this matter, see recently Olga Bush, "Poetic Inscriptions and Gift Exchange in the Medieval Islamicate World," Gesta 56/2 (2017): 179-197.

15 For the larger context of contacts, especially bellicose, between Scandinavia and Iberia, see Ann Christys, Vikings in the South: Voyages to Iberia and the Mediterranean (London: Bloomsbury Publishing, 2015). 
were acquired as Reconquest booty,"16 while Avinoam Shalem tells us that they are "perhaps best understood as trophies of war."17 Although this triumphalist interpretation holds true for some pieces, it should not be seen as representative for the whole. Rather, I second the approach taken recently by Mariam Rosser-Owen, who proposes "alternative modes of transfer between the cultures." ${ }^{18}$ In discussing the well-documented sack of the Fatimid treasury in late eleventh-century Cairo, Rosser-Owen makes a chronological point of particular relevance to San Isidoro and the founding of its treasury by Fernando and Sancha. She underscores that the looting of Fatimid objects occurred around 1069, which means that the silver niello casket bearing the name Sadaqa ibn Yusuf was unlikely to have made its way to León via al-Andalus until some time after that moment (Figure 2.2; no. IIC-3-089-002oo14).$^{19}$ If, as most scholars presume, the metalwork object left Egypt through this act of spoliation, it could neither have been part of the 1063 donation, around which the entire historiography of the Isidoran treasury has revolved (a thorny question I parse out in detail below), nor would the box have reached its destination until after the deaths of the treasury's founders: Fernando in 1065 and Sancha two years later. The Fatimid casket at San Isidoro must therefore be associated with one of their descendants rather than with the moment of foundation.

16 Julie Harris, "Muslim Ivories in Christian Hands: The Leire Casket in Context," Art History 18/2 (1995): 213-221, esp. 213.

17 As stated in the opening sentence of Avinoam Shalem, "From Royal Caskets to Relic Containers: Two Ivory Caskets from Burgos and Madrid," Muqarnas 12 (1995): 24-38. Shalem also makes an un-cited reference to "luxury ivory caskets which were looted by Christians from the royal palaces in the main capitals of the Islamic kingdoms of Spain" (p. 25). In fact, it is not possible to trace definitively to looting any existing ivory casket from its original Islamic setting to its later Christian holding. See also Shalem, Islam Christianized: Islamic Portable Objects in the Medieval Church Treasuries of the Latin West (Frankfurt-am-Main: Peter Lang, 1996); Shalem, "Islamische Objekte in Kirchenschätzen der lateinischen Christenheit: Ästhetische Stufen des Umgangs mit dem Anderen und dem Hybriden," in Das Bistum Bamberg in der Welt des Mittelalters, ed. Christine and Klaus van Eickels (Bamberg: University of Bamberg Press, 2007), 163-176.

18 Mariam Rosser-Owen, "Islamic Objects in Christian Contexts: Relic Translation and Modes of Transfer in Medieval Iberia," Art in Translation 7/1 (2015): 39-64, esp. 48.

19 The box itself can be dated indirectly to 1044-1047, the years during which the inscription's dedicatee oversaw the treasury as vizier to the Fatimid caliph. See Stefano Carboni, "Casket," in The Art of Medieval Spain, AD 500-1200, exh. cat. (New York: Metropolitan Museum of Art, 1993), 99-100. For the ransacking of the Fatimid treasury, the date 1067-1068-equally too late for the 1063 donation to San Isidoro-is given by Richard Ettinghausen, Oleg Grabar, and Marilyn Jenkins, Islamic Art and Architecture 650-1250 (New Haven: Yale University Press, 2001), 200. 


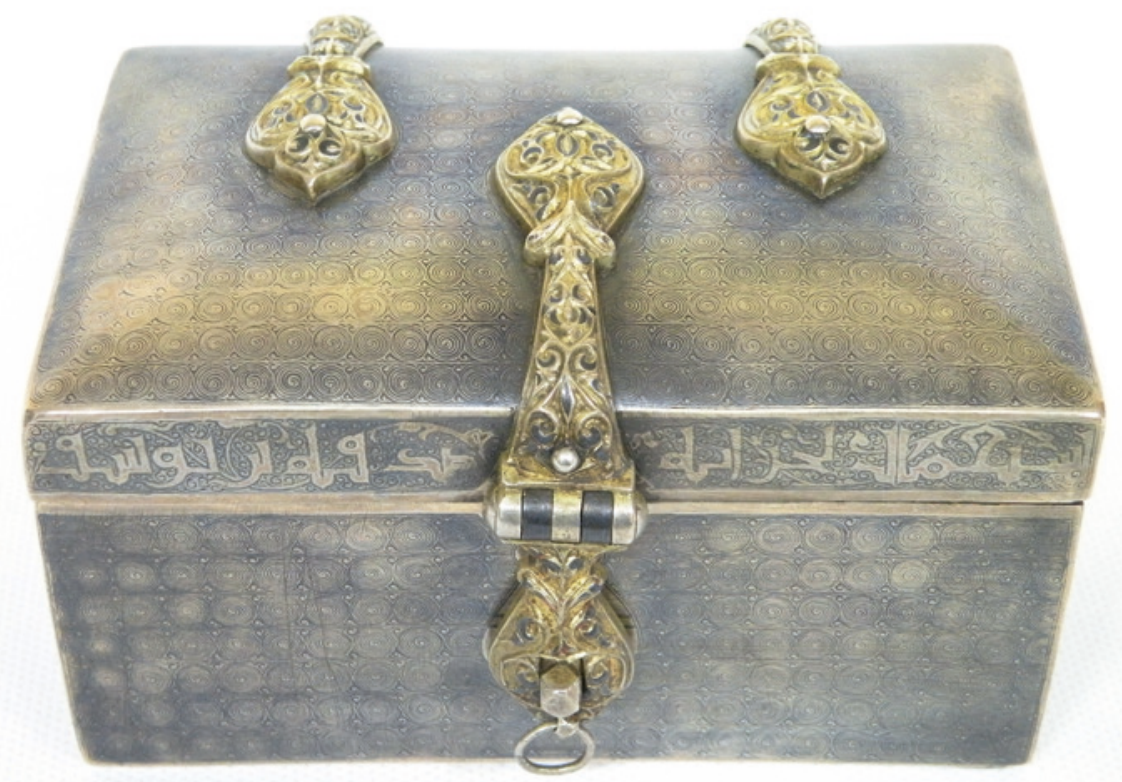

FIGURE 2.2 Silver Fatimid casket, 1044-1047? (Museo de la Real Colegiata de San Isidoro de León, Inv. No. IIC-3-089-002-0014). PHOTO: THERESE MARTIN

War booty, despite its relevance for given pieces and its emphasis in medieval chronicles, ${ }^{20}$ is no longer the default position to explain the presence of foreign objects in Iberian treasuries. Long-distance commercial interchange, and in particular the importance of ivory trade networks across the Islamic lands, sub-Saharan Africa, and southern Italy has been fruitfully studied by Sarah Guérin. ${ }^{21}$ Further, Eva Hoffman's concept of "the shared vocabulary of luxury" has proven a particularly instructive model to explain the larger phenomenon from both Islamic and Christian perspectives. ${ }^{22}$ The aptness of such an approach can be seen clearly in treasuries like the one at San Isidoro, in which a

$20 \quad$ See the contribution to this volume by Ana Rodríguez.

21 Sarah M. Guérin, "Forgotten Routes? Italy, Ifriqiya and the Trans-Saharan Ivory Trade," AlMasaq 25/1 (2013): 70-91. For the Iberian Peninsula, see Manuel Casamar and Fernando Valdés, "Saqueo o comercio: la difusión del arte Fatimí en la Península Ibérica," Codex Aquilarensis 14 (1999): 133-16o.

22 Eva Hoffman, "Pathways of Portability: Islamic and Christian Interchange from the Tenth to the Twelfth Century," Art History 24 (2001): 17-50, esp. 26; Hoffman, "Translation in Ivory: Interactions across Cultures and Media in the Mediterranean during the Twelfth and Thirteenth Centuries," in Siculo-Arabic Ivories and Islamic Painting 1100-1300. 
Fatimid box shared space with a diminutive Scandinavian container, a Limoges reliquary, and other geographically distinct works, including a multitude of locally produced ivories, as we shall see below. Such scholarly approaches encourage a conceptual shift away from the focus on religious triumphalism and toward a recognition of the geographic resonance of objects. At San Isidoro, the presumed royal and ecclesiastical audience for these precious containers would have appreciated the prestige inherent in the luxury materials as well as in the objects' origination in distant lands. Such ideas play out as well in the study in this volume by Pamela Patton, where the eyes of the sophisticated Leonese viewers are trained on painted imagery. ${ }^{23}$

Kinship across the cultures as a mode of object transfer is another fresh tack taken by Glaire Anderson, who reads the making of the San Millán cross in the caliphal ivory workshops as a result of the family relationship between Queen Toda of Navarra (fl. 928-959) and her nephew the caliph 'Abd al-Rahmān III (d. 961). ${ }^{24}$ Juan Carlos Ruiz Souza adduces other forms of gift exchange among rulers in medieval Iberia, ${ }^{25}$ and the studies centering on cross-cultural uses of textiles by María Judith Feliciano are particularly illuminating in this area. ${ }^{26}$ Additional attention should be drawn to a relatively underappreciated alternative mode of object transfer, a subset of the well-studied diplomatic gift exchange: ${ }^{27}$ marriage as a significant conduit for the long-distance, and at times cross-cultural, movement of luxury items. In marriage, elite women themselves embody exchange, and they both cement and personify alliances as they cross from natal lands to new places. ${ }^{28}$ There they are assimilated into

Proceedings of the International Conference, Berlin, 6-8 July 2007. Römisches Jahrbuch der Bibliotheca Hertziana, vol. xxxvi, ed. D. Knipp (Munich: Hirmer Verlag, 2011), 100-119.

23 Pamela A. Patton, "Demons and Diversity in León."

24 Glaire D. Anderson, "Sign of the Cross: Contexts for the Ivory Cross of San Millán de la Cogolla," Journal of Medieval Iberian Studies 6/1 (2014):15-41.

25 Juan Carlos Ruiz Souza, "Botín de guerra y tesoro sagrado," in Maravillas de la España medieval. Tesoro sagrado y monarquía, ed. Isidro Bango Torviso (Valladolid: Junta de Castilla y León, 2001), 1:31-39.

26 María Judith Feliciano, "Muslim Shrouds for Christian Kings? A Reassessment of Andalusi Textiles in Thirteenth-Century Castilian Life and Ritual," in Under the Influence: Questioning the Comparative in Medieval Castile, ed. Cynthia Robinson and Leyla Rouhi (Leiden: Brill, 2005), 101-131; Feliciano, "Medieval Textiles in Iberia: Studies for a New Approach," in Envisioning Islamic Art and Architecture: Essays in Honor of Renata Holod, ed. David J. Roxburgh (Leiden: Brill, 2014), 46-65.

27 For an admirably concise assessment of the complex issues involved in gift exchange, see Cecily Hilsdale, "Gift," Medieval Art History Today, Critical Terms, ed. Nina Rowe, special issue, Studies in Iconography 33 (2012): 171-182.

28 See, for example, Jitske Jasperse, "Matilda, Leonor and Joanna: The Plantagenet Sisters and the Display of Dynastic Connections through Material Culture," Journal of Medieval 
their husbands' lines while bringing something of their own along: traditions, languages, names, and even kin, as well as objects. Through their marriages, elite women became the key contact points in political-cultural networks. The Eleanor Vase, ${ }^{29}$ discussed by Ana Rodríguez in her contribution to this volume, is among the best-known of examples, but as the author further points out, Constanza (d. 116o), the daughter of Alfonso VII of León-Castilla, who was Eleanor's successor as wife of Louis VII of France, is also said to have brought a marriage gift from Islamic Iberia to her husband. ${ }^{30}$ Neither Eleanor's gift nor Constanza's was unique; rather, both are representative of the widespread movement of medieval objects from one land to another in which women played key roles.

At the treasury of San Isidoro, we have a heretofore unrecognized example of the acquisition of luxury goods from distant lands through marriage. A set of three Sicilian ivory boxes, whose presence in León has never been explained, are best understood in light of the marriage in 1117 of the infanta Elvira (d. 1135; daughter of Alfonso VI) to Roger II of Sicily (r. as count 1112-1130, as king 1130-1154). According to Silvia Armando, this type of cylindrical container with painted decoration fits neatly into the context of the 1120s, in which highquality sets of ivories were produced and exported from Sicily and southern Italy (Figure 2.3; nos. IIC-3-089-002-0o11, -0012,-o013). ${ }^{31}$ These ivory boxes were designed for elite purposes, both lay and ecclesiastic, as containers for a ruler's riches or for sacred remains. The three pyxides in León offer material evidence for the otherwise unattested negotiations that must have taken place between

History 43/5 (2017): 523-547; Tracy Chapman Hamilton and Mariah Proctor-Tiffany, eds., Moving Women, Moving Objects, 300-1500 (Leiden: Brill, 2019).

29 George T. Beech, "The Eleanor of Aquitaine Vase, William IX of Aquitaine, and Muslim Spain," Gesta 32 (1993): 3-10; Beech, "The Eleanor of Aquitaine Vase," in Eleanor of Aquitaine. Lord and Lady, ed. Bonnie Wheeler and John Carmi Parsons (New York: Palgrave Macmillan, 2003), 369-373.

30 "Like the gem of Zafadola, the Fatimid rock crystal jug of Mitadolus ended up in the treasury of the great Parisian abbey of Saint Denis, both presented by King Louis viI of France after receiving them from his two wives: the vase from the first, Eleanor, the gem from the second, Constanza." See Chpt. 3, Ana Rodríguez, "Narrating the Treasury: What Medieval Iberian Chronicles Choose to Recount about Luxury Objects."

31 Silvia Armando, "Caskets Inside Out. Revisiting the Classification of 'Siculo-Arabic' Ivories," Journal of Transcultural Medieval Studies 4/1-2 (2017): 51-145. For a detailed assessment of dating issues, see Armando, "Avori 'arabo-siculi' nel Mediterraneo medievale," PhD diss., Università degli Studi della Tuscia, Viterbo, 2012, 1:6o-63. The author currently has a study underway addressing Elvira and the Palermo-León connection; I am grateful to her for our fruitful discussions on this matter. See also Noelia Silva Santa-Cruz, "The Siculo-Arabic Ivories and Their Spreading to al-Andalus," Journal of Transcultural Medieval Studies 4/1-2 (2017): 147-19o. 


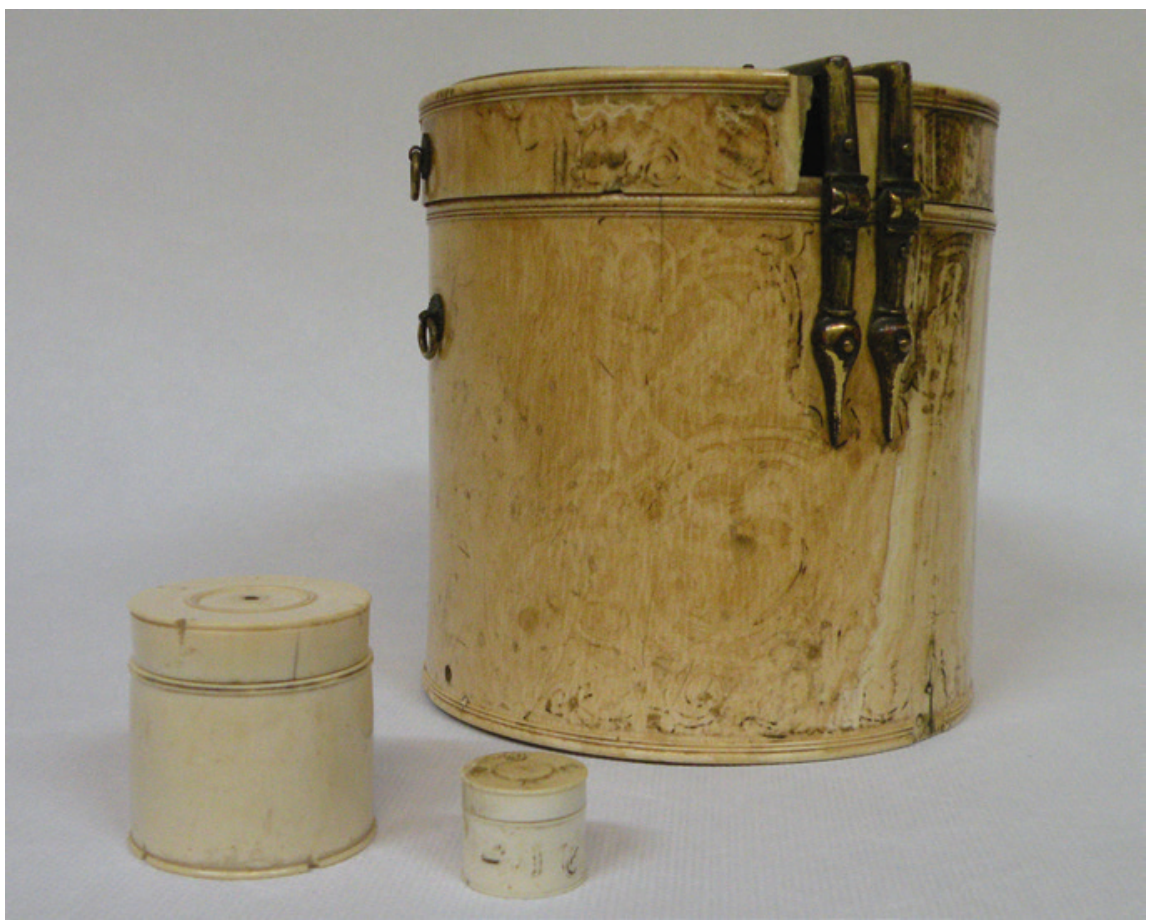

FIGURE 2.3 Sicilian ivory set, 1120s? (Museo de la Real Colegiata de San Isidoro de León, Inv. Nos. IIC-3-089-002-0011, 0012, 0013). PHOTO: THERESE MARTIN

the count of Sicily and Queen Urraca of León-Castilla (r. 1109-1126), which resulted in the alliance that sent her half-sister to Palermo. ${ }^{32}$ Elvira bore five sons and a daughter before she died in 1135, having been raised to the status of queen five years earlier when Roger was crowned king in 1130. Although we

Elvira and Urraca were daughters of Alfonso Vi (r. 1065-1109). Urraca was his eldest child, born ca. 1080 to his second wife, Constanza of Burgundy (d. 1093). Elvira was born ca. 1103, the second daughter of Alfonso's fifth consort, Isabel (d. 1107). In 1116, Elvira and her full sister Sancha confirmed a donation to the cathedral of León as Sancia et Geloira eiusdem regine sororibus, domum Sancti Pelagii regentibus, indicating that they ruled over the infantazgo at that time. For Elvira and Sancha, see José María Fernández Catón, Colección documental del archivo de la Catedral de León (775-1230) (León: Centro de Estudios e Investigación San Isidoro, 199o), 5:52-56; María Encarnación Martín López, Patrimonio cultural de San Isidoro de León: Documentos de los siglos X-XIII (León: Universidad de León, 1995), 38-39; Carlos Reglero de la Fuente, "Omnia totius regni sui monasteria: la Historia Legionense, llamada Silense y los monasterios de las infantas," e-Spania 14/Dec. 2012; DOI: 10.4OOo/e-spania.21775. 
cannot know exactly when the Sicilian ivories arrived at San Isidoro, it is most likely to have occurred during Elvira's lifetime, either related to her marriage or as a gift she sent back to León. These ivory pyxides are themselves a visual source that fills a silence in the written register and, further, they speak to the movement of elite women as vectors of medieval culture. They are also crucial for understanding the evolution of the treasury at San Isidoro.

Although some of the objects from the Isidoran treasury have received sustained scholarly attention, others are all but unknown outside León; moreover, works of Islamic or Christian manufacture have been addressed primarily in studies that separate the pieces by the origin of production. But the common factor that unifies all research on the various pieces in the treasury is their attribution to a great donation by the monarchs who ruled over León-Castilla in the mid-eleventh century, Fernando and Sancha. And while it is indeed likely that the initial creation of the treasury stemmed from the impetus of this ambitious couple, both written and visual sources offer evidence for the continued growth of the treasury after their deaths, as shown by the chronologies of the Fatimid box and the Sicilian ivories. It is essential, therefore, to reassess the chronology of the treasury's initial foundation in order to weigh the significance of its later elaboration.

\section{A Closer Look at the 1063 Donation}

In 1063, the relics of the confessor Isidore (d. 636) were translated from Sevilla to the capital of the kingdom of León-Castilla. An account contemporary with Isidore's translation provides the basic information about the Visigothic saint's installation in León. ${ }^{33}$ The remains were deposited with great pomp in a ceremony of re-consecration at the royal monastic church and palatine chapel dedicated to John the Baptist, which had been built around 1055 by Fernando and Sancha. ${ }^{34}$ San Juan Bautista was the male half of a mixed community, whose female religious members were under the advocation of the Iberian

33 José Carlos Martín, “La Translatio S. Isidori Legionem Anno 1063(BHL 4488): Introducción, estudio y edición crítica," Exemplaria Classica.Journal of Classical Philology 15 (2011): 225253. See also Patrick Henriet, "Un exemple de religiosité politique: saint Isidore et les rois de León (XIe-XIIIe siècles)," in Fonctions sociales et politiques du culte des saints dans les societés de rite grec et latin au Moyen Âge et à l'époque moderne: approche comparative, ed. Marek Derwick and Mikhail Vladimirovich Dmitriev (Wroclaw: Larhcor, 1999), 75-95.

34 On the history of the monastery in the eleventh century, see Therese Martin, Queen as King: Politics and Architectural Propaganda in Twelfth-Century Spain (Leiden: Brill, 2006), 30-61. 
martyr Pelayo (d. 925), a comely youth who died in Córdoba after rejecting the advances of the ruler 'Abd al-Rahmān III. ${ }^{35}$ Of the mid-eleventh-century church that received Isidore's bones, two partial walls still stand, incorporated into the later Romanesque construction; the complete foundations of Fernando and Sancha's church are known through the work of John Williams. ${ }^{36}$

A second documentary source, purporting to date from the same moment and detailing a grand donation of luxury goods and extensive lands, tells us that 1063 was also the occasion for the rich endowment of the church by the ruling couple. ${ }^{37}$ The charter, much loved by art historians for its remarkably detailed character, has been used to associate the entirety of the treasury at San Isidoro with this single moment in time. Such a position, however, is complicated by the existence of multiple objects from the twelfth century. Beyond the pieces that post-date 1063, the date of the charter itself has long been recognized as problematic and, in 2007, the paleographer Encarnación Martín López demonstrated for it a definitive twelfth-century date: the document was written in a hand imitating Visigothic script by someone who normally uses Caroline. ${ }^{38}$ Rather than a forgery in the modern sense of the word, she analyzes the document as a sort of mini-cartulary, in which three or more possibly original charters have been merged together to create a maxi-donation. This understanding of the document as a later compilation serves as a cautionary tale for our investigation of the treasury; it also changes the way we think about the multiple layers of history at a treasury and prompts us to consider possible motivations for royal donations and the narratives that arise around them.

The "1063 charter" opens with a first-person declaration by Fernando and Sancha, in which it is stated that they

have arranged the translation of Saint Isidore's body by the hands of bishops and priests from the metropolitan church of Sevilla to the church of Saint John the Baptist, within the walls of our city, León. We offer,

35 See Jeffrey A. Bowman, "Beauty and Passion in Tenth-Century Córdoba," in The Boswell Thesis: Essays on Christianity, Social Tolerance, and Homosexuality, ed. Mathew Kuefler (Chicago: University of Chicago Press, 2006), 236-253.

36 See especially John Williams, "San Isidoro Exposed: The Vicissitudes of Research in Romanesque Art," Journal of Medieval Iberian Studies 3/1 (2011): 93-116.

37 Archivo de San Isidoro de León, no. 125.

38 María Encarnación Martín López, "Un documento de Fernando I de 1063: ¿Falso diplomático?" in Monarquía y sociedad en el reino de León. De Alfonso III a Alfonso VII, II, Fuentes y Estudios de Historia Leonesa 118 (León: Centro de Estudios e Investigación San Isidoro, 2007), 513-540. She argues that that the parchment's large size, layout, abbreviations, and angularity of letters all indicate a twelfth-century hand. 
therefore, in the presence of bishops and many men of religion who have come from different regions, motivated by the desire to honor devotedly such great solemnity, to the aforementioned place of Saint John the Baptist and Saint Isidore, these altar ornaments. ${ }^{39}$

What follows is a verbal display ${ }^{40}$ of magnificent goods that helps to imagine how the visual display would once have made the stone church of San Isidoro shine with metalworks, silks, and ivories.

A pure gold altar frontal of fine manufacture with emeralds, sapphires, and all manner of precious stones and enamel (glass/crystal? olouitreis);

similarly, three other silver frontals, one for each altar; three golden crowns: one with six alphas around it, another with pearls hanging within, and another golden one with pearls (amethysts? annemates) and enamels:

in fact, the third one is the golden diadem from my own head; a small crystal casket covered in gold, a golden cross studded with precious stones and enamels, and another in ivory with the figure of our crucified redeemer, two golden thuribles with their incense holders also of gold, and another cast silver censer of great weight, and a chalice and paten made of gold and enamels. Golden stoles with luxury silver fabric (amocerce $)^{41}$ worked in gold, and also a luxury silver fabric with enamel/crystal appliqué (olouitrea). An ivory casket worked with gold, and two more ivory caskets decorated with silver:

39 Martín López, "Un documento de Fernando I," 536. "fecimus translatari corpus beati Hysidori de metropolitana Hispali per manus episcoporum siue sacerdotum intra muros Legionis ciuitatis nostre in ecclesia Sancti Iohannis Babtiste. Offerimus igitur in presencia episcoporum nec non multorum uirorum religiosorum, qui ex diuersis partibus aduocati ad ho [sic] honorem [sic] tante sollempnitatis deuote uenerunt, eidem Sancti Iohanni Babtiste et beato Ysidoro in predicto loco ornamenta altariorum ..." I am very grateful to Eduardo Fernández Guerrero for providing a new translation of this document, and to Kenneth Baxter Wolf and Hannah Thomson for helping me to hone the wording.

40 On the reading aloud of documents like the "1063 charter," see Liam Moore, "By Hand and Voice: Performance of Royal Charters in Eleventh- and Twelfth-Century León," Journal of Medieval Iberian Studies 5/1 (2013): 18-32.

41 For translations of the different terms used for textiles in the 1063 donation, see Chpts. 4 and 5 by Ana Cabrera and María Judith Feliciano in the present volume. 
inside one of these are three small caskets of the same material.

And diptychs carved in ivory.

Three altar frontals with gold embroidery,

a large brocaded temple veil together with two smaller ones with

ermine fur;

two mantles embroidered in gold,

and a gold-embroidered textile,

and another purple-bordered Byzantine textile (grizisco in dimisso

cardeno),

also a golden-edged chasuble and two dalmatics embroidered in gold, and a silk cloth embroidered with gold.

An altar service, that is,

a salt cellar,

a platter (inferturia),

a pair of tongs

a pitcher with ten cups,

two golden candlesticks,

a mysterious (?) golden object (anigma exaurata),

and a ewer.

All of these containers, both silver and golden, as well as the

aforementioned ewer, have two handles. ${ }^{42}$

Given the detailed enumeration of the objects, with especially varied and evocative attention to sumptuous materials, it is no wonder that this text has

42 Martín López, “Un documento de Fernando I," 536-537: “... ornamenta altariorum, id est: frontale ex auro puro opere digno cum lapidibus zmaracdiis, saffiris et omni genere preciosis et olouitreis, alios similiter tres frontales argenteos singulis altaribus, cororonas (sic) tres aureas, una ex his cum sex alfas in giro et corona de alaules intus in ea pendens alia est de annemates cum olouitreo aurea, tercia uero est diadema capitis mei aurea, et arcellina de cristallo auro cooperta, et crucem auream cum lapidibus conpertam olouitream, et aliam eburneam in similitudinem nostri redemptoris crucifixi, turibulos duos aureis cum inferturia aurea et alium turibulum argenteum magno pondere conflatum, et calicem et patenam ex auro cum olouitreo, stolas aureas cum amoxerce argenteo et opera ex auro, et aliud argenteum adamorcece habet opera olouitrea, et capsam eburneam operatam cum auro, et alias duas eburneas argento laboratas: in una ex eis sedent intus tres alie capselle in eodem opere facte et dictacos calpertiles eburneos, frontales tres aurifrisos, uelum de templo lotzori maiore cum alios duos minores arminios, mantos duos aurifrisos, alio alguexi auro texto cum alio grizisco in dimisso cardeno. Casula aurifrisa cum dalmaticis duabus aurofrisis et alia aluexi auro texta, servicio de mensa, id est, salare, inferturia, tenaces, trullione com coclearibus X, ceroferales duos deauratos, anigma exaurata et arrotoma, omnia haec uasa argentea deaurata cum predicta arrotoma binas habent ansas." 
been of central importance to art historians..$^{43}$ And yet in light of the reattribution of the surviving document to an undefined time in the twelfth century, it becomes necessary to widen our parameters of interpretation beyond 1063. Martín Lopez interpreted the confection of this charter as a response to the need for a written guarantee of the rights and privileges of the monastery. I would like to propose two possibilities in which the social and political context would have been ripe for the writing of such a document. Each is a time of discord during which the charter would have acted as a buttress, recalling a powerful moment by rulers past, who were themselves the founders both of San Isidoro and of the ruling dynasty. ${ }^{44}$ The candidates are Queen Urraca during the first part of her reign, 1109-1117, or her children, King Alfonso VII and his only full sibling Infanta Sancha around the years 1144-1148.

As is well known, the early years of the reign of Urraca were extremely unstable; 45 no one can doubt the need for a document during this time to reiterate rights, properties, and goods, but also to emphasize prestigious lineage and the ambitions to rule. As Martín López points out, the size of the supposed 1063 parchment, at $670 \times 500 \mathrm{~mm}$, is closest to the large size of several of Urraca's charters $(680 \times 520 \mathrm{~mm})$, although some of those written during the reigns of Alfonso VI and Alfonso VII also approach its dimensions. ${ }^{46}$ Urraca's political situation had improved by 1117 , when she was secure enough to negotiate a truce with her estranged husband, Alfonso I el Batallador of Aragón (r. 11041134); this was renewed every three years until her death in 1126 . Also in 1117 , the queen made a major donation to San Isidoro of monasteries and territories in and around León, greatly increasing its holdings. ${ }^{47}$ From this moment on, the

43 It is worthy of note that no books appear in this list, especially given the four surviving books that bear Sancha's name, once on her own, two of them together with Fernando, and once with her son Sancho. On these books and for previous bibliography, see Therese Martin, "Fuentes de potestad para reinas e infantas: el infantazgo en los siglos centrales de la Edad Media," El ejercicio del poder de las reinas ibéricas, ed. Ana Echevarría and Nikolas Jaspert, special issue, Anuario de Estudios Medievales 46/1 (2016): 97-136, esp. 103-111.

44 John B. Freed has argued that the 116o Codex Falkensteinensis of Count Siboto IV of Falkenstein (Munich, Bayerische Hauptstaatsarchiv, BayHStA KL Weyarn 1) is an example of cartularies made in times of insecurity; see his "Artistic and Literary Representations of Family Consciousness," in Medieval Concepts of the Past: Ritual, Memory, Historiography, ed. Gerd Althoff, Johannes Fried, and Patrick J. Geary (Cambridge: Cambridge University Press, 2002), 233-252. See also Elisabeth Noichl, Codex Falkensteinensis: Die Rechtsaufzeichnungen der Grafen von Falkenstein (Munich: C. H. Beck, 1978).

45 On this context, see José Luis Senra, "Rebellion, Reconciliation, and a Romanesque Church in León-Castile (c. 1109-1120)," Speculum 87/2 (2012): 376-412.

46 Martín López, "Un documento de Fernando I," 519.

47 Published in Encarnación Martín López, Patrimonio cultural de San Isidoro de León: Documentos de los siglos X-XIII (León: Universidad de León, 1995), 40-42. 
final decade of her reign was little different from that of any other monarch of her day.

Our second pair of candidates are Urraca's eldest children Sancha and Alfonso, born to her first husband Count Raimundo of Burgundy ${ }^{48}$ Alfonso viI reigned over León-Castilla from 1126 to 1157, while Sancha ruled the inheritance known as the infantazgo from 1127 until her death in 1159. The network of royal monasteries that made up the infantazgo was controlled by royal daughters and the crown from its caput at the mixed monastic community of San Isidoro. ${ }^{49}$ During the years 1144-1148, great changes were afoot at San Isidoro, culminating in the removal of the nuns to Carbajal, outside León, and the installation of Augustinian canons in their place. ${ }^{50}$ If the "1063 charter" were made in this moment, it would serve to calm the roiled waters while guaranteeing the nearly century-old rights, privileges, and liturgical treasury. The intense attention paid to San Isidoro by the infanta Sancha after the arrival of the Augustinians plays out across nine donations made 1148-1158, some by her alone, some with her brother the king. Although none of these charters references liturgical goods, a portable altar bearing Sancha's name, as with the chalice of her great-aunt Urraca, testifies to the tradition of gift-giving by the rulers of the infantazgo at San Isidoro. Sancha's remarkable portable altar is the focus of the study in this volume by Jitske Jasperse, who looks closely into the question of the infanta as patron of luxury objects. ${ }^{51}$

Given the significance to twelfth-century political life of the 1063 events at San Isidoro-both the saint's translation and the church's rededication-we should be wary of attributing too much documentary weight to the charter for

48 No children were born of Urraca's marriage to Alfonso I of Aragón. With her third consort, Count Pedro González de Lara, she gave birth at least four more times, but only two of the children are known to have survived, Fernando and Elvira.

49 See Patrick Henriet, "Deo votas: L'Infantado et la fonction des infantes dans la Castille et le León des Xe-XIIe siècles," in Au cloître et dans le monde: Femmes, hommes et sociétés (IXe-XVe siècles), Mélanges en l'honneur de Paulette L'Hermite-Leclercq (Cultures et Civilisations médiévales, 23), ed. Patrick Henriet and Anne-Marie Legras (Paris: Presses de l'université de Paris-Sorbonne, 2000), 189-203; 5/junio 2008, special issue of $e$-Spania, especially Patrick Henriet, "Infantes, Infantaticum. Remarques introductives," (DOI 10.400o/e-spania.12593), and Therese Martin, "Hacia una clarificación del infantazgo en tiempos de la reina Urraca y su hija la infanta Sancha (ca. 1107-1159)," (DOI: 10.400o/espania.12163). See also Carlos Reglero de la Fuente, "Los testamentos de las infantas Elvira y Sancha: monasterios y espacios de poder," in Mundos medievales: espacios, sociedades y poder. Homenaje al Profesor José Ángel García de Cortázar y Ruiz de Aguirre, ed. Beatriz Arízaga Bolumburu et al. (Santander: Universidad de Cantabria, 2012), 1:835-847.

50 See Martin, Queen as King, 158-161.

$5^{1}$ See Chpt. 6, Jitske Jasperse, "Between León and the Levant: The Portable Altar of the Infanta Sancha as Material Evidence for Medieval History." 
establishing the original offerings by Fernando and Sancha. In fact, as every scholar working on objects from San Isidoro's collection has noted, at least in passing, the lone piece that can now be recognized from the list is an ivory crucifix (Figure 2.4a; inv. no. 52340). ${ }^{52}$ This was one of six objects belonging to San Isidoro that were requisitioned by a government commission in 1869 to become part of the new national archaeological museum in Madrid, an extraordinary number of pieces to have been appropriated from a single monument. ${ }^{53}$ In the 1063 donation, this magnificent object appears as "another [cross] of ivory with a representation of our crucified Redeemer." ${ }^{\prime 4}$ The ivory cross itself is carved front and back in both low and high relief, while the separate ivory corpus is fully sculpted in the round; the complete object weighs in at a substantial 1,293 grams ( $2.85 \mathrm{lbs}$.) of solid ivory. An inscription in two registers at the foot of the cross, beneath the bent figure of Adam, lays claim to the work: FREDINANDUS REX, SANCIA REGINA (Figure 2.4b). Certainly, the royal couple are responsible for this crucifix, and it is indeed probable that such a stunning offering would have been commissioned to mark a major occasion like the rededication of their church at the arrival of Isidore's relics.

But beyond this single item, none of the multiple golden objects listed in the "1063 charter" survives. Of the liturgical textiles, even when a reference to the material, like gold embroidery or purple silk, might suggest a surviving object, the phrasing is too generic to make definite identification possible, although one might try to make a case for the tenth-century embroidery discussed in the contributions to this volume by Ana Cabrera and María Judith Feliciano. Such general descriptions also apply to the ivory caskets in the charter; in fact, it was the very insistence on multiple works of ivory that initially spurred me to pay closer attention to the "1063 charter," for it is quite unusual to find more than a piece or two of ivory listed in Iberian inventories of the early and central Middle Ages. ${ }^{55}$ And it is true that San Isidoro boasts an extraordinary collection of ivories, though

$5^{2}$ See Manuel Gómez-Moreno, En torno al crucifijo de los reyes Fernando y Sancha (Madrid: Ministerio de Educación Nacional, Dirección General de Bellas Arte, 1965); Franco Mata, "El tesoro de San Isidoro;" Franco Mata, Arte leonés fuera de León (ss. IV-XVI) (León: Edilesa, 2012); Noemi Álvarez da Silva, "El trabajo del marfil en la España del siglo XI," PhD diss., Universidad de León, 2014, 84-151.

53 The nineteenth-century context and the role of the newly founded museum in nation-building are currently being studied by Amanda Dotseth. I am grateful to her for sharing her research with me.

54 "Et aliam eburneam in similitudinem nostri redemptoris crucifixi."

55 See the founding donations discussed by Ana Rodríguez, "À propos des objets nécessaires: dotations monastiques et circulation d'objets au royaume de León dans le haut Moyen Âge," in Objets sous contraintes: Circulation des richesses et valeur des choses au 

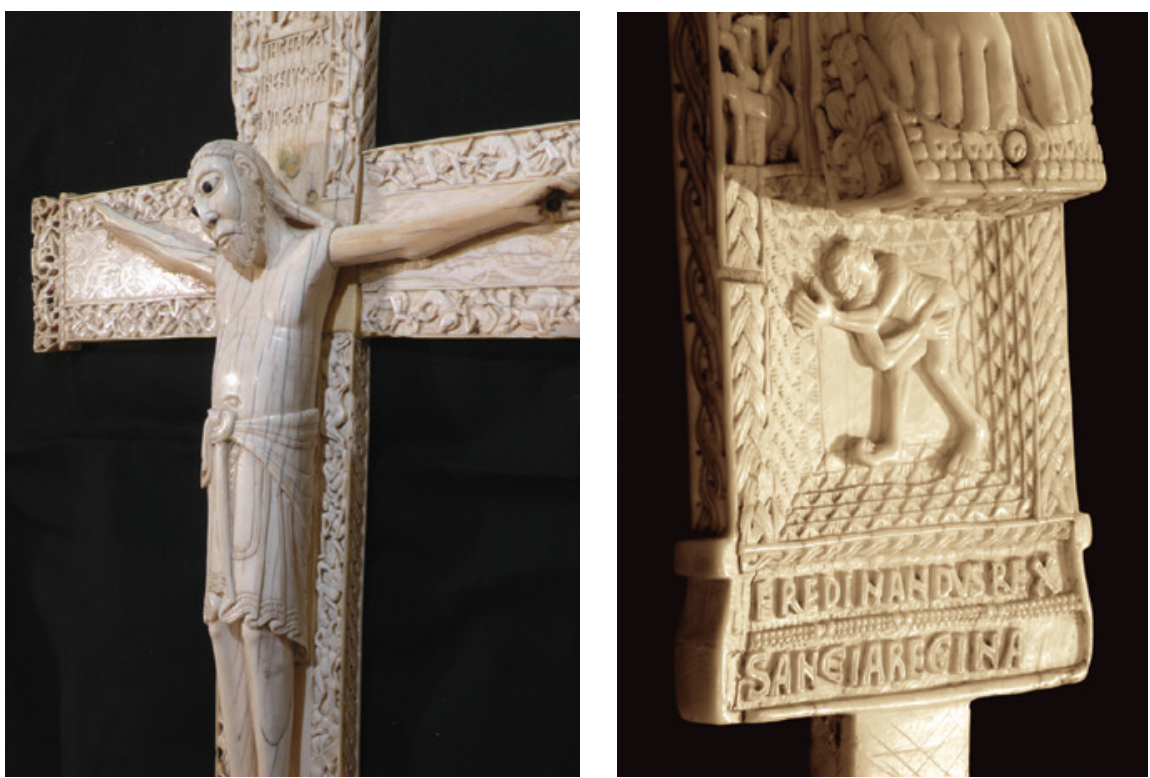

Figures 2.4A, B Crucifix of Fernando and Sancha, 1063? (Museo Arqueológico Nacional, Inv. No. 52340). See also Fig. 6.6.

PHOTOS: THERESE MARTIN

none that has come down to us today is worked with gold or silver, as specified in the charter. Yet scholars have gone to great lengths in frustrated attempts to recognize more than just the crucifix in the pieces listed in this document. If, for a treasury like Saint-Denis, much energy has successfully been spent on matching up objects and written sources, for San Isidoro I would instead propose that we ask new questions of both the treasury and its beloved charter, interrogating the goals behind the creation of the collection in the eleventh century while assessing the magnitude of its development in the twelfth century, and thereafter. ${ }^{56}$

Despite the fact that the foundational donation as it has come down to us cannot be taken at face value, it is safe to say that Fernando and Sancha would have

Moyen Âge, ed. Laurent Feller and Ana Rodríguez (Paris: Publications de la Sorbonne, 2013), 63-89.

56 On other "thereafters," see The Long Lives of Medieval Art and Architecture, ed. Jennifer M. Feltman and Sarah Thompson, AVISTA Studies in the History of Medieval Science, Technology, and Art (Abingdon: Routledge, 2019). 
given generously to the church attached to their royal palace, both at the time of construction a decade earlier and in 1063 when Isidore was added to its titular saints. Further evidence of their artistic commissions can be seen in four books bearing their names: a Beatus Commentary on the Apocalypse, which is discussed by Pamela Patton in her contribution to this volume, two prayerbooks, and a miscellanea. ${ }^{57}$ Their eldest daughter Urraca can also be confirmed as a patron of this church, most likely after 1067, the year of Sancha's death, when the infanta became head in her mother's place of the infantazgo of San Pelayo and San Isidoro. ${ }^{58}$ At least one magnificent gift on the infanta's part is attested by the surviving chalice made of two Antique sardonyx cups encircled by a gold-filigreed inscription that reads IN NOMINE D[OMI]NI VRRACA FREDINA[N]DI (Figure 2.5). In the eighteenth century, a now lost crucifix naming Urraca was also seen at San Isidoro by two viewers who described it as a monumental bejeweled gold cross bearing an ivory corpus, at the foot of which was a high-relief representation of the infanta. ${ }^{59}$ Manuel Risco's 1792 publication details her depiction:

At the foot of the crucifix one reads the word MERCY and then, URRACA, DAUGHTER OF KING FERNANDO AND QUEEN SANCHA. On the lower part of the cross the same doña Urraca is shown kneeling, her hands together, raised and extended, and her name repeated in letters that begin above her head and go down before her, extending almost the full length of the figure. ${ }^{60}$

Concerning the infanta Urraca, the so-called Historia Silense (ca. 1118-1130) echoes her gifts of luxury items such as the chalice and cross, stating in general terms that "all of her life she followed her desire to adorn sacred altars and the

57 See Chpt. 7, Pamela Patton, "Demons and Diversity in León." See also Martin, "Fuentes de potestad para reinas e infantas," 103-111.

$5^{8}$ On the infantazgo, see note 49 and recently Lucy Pick, Her Father's Daughter: Gender, Power and Religion in the Early Spanish Kingdoms (Ithaca: Cornell University Press, 2017).

59 José Manzano, Vida y portentosos milagros del glorioso San Isidro, arzobispo de Sevilla, con una breve descripción de su magnífico templo y real casa del mismo señor San Isidro en la muy noble ciudad de León (Salamanca: Imprenta Real, 1732), $35^{2}$ and 383. He records the inscription as "Urraca, Regis Ferdinandi filia \& Sanchiae Reginae donavit" and gives the height as "dos varas y media y lo ancho de los brazos de vara y media."

6o Manuel Risco, Iglesia de Leon, y monasterios antiguos y modernos de la misma ciudad (Madrid: En la oficina de Don Blas Román, 1792), 146-147. "Debaxo de los pies del crucifixo se lee esta palabra: MISERICORDIA, y luego: VRRACCA FREDINANDI REGIS ET SANCIA REGINA FILIA; y en la parte inferior de la Cruz se representa la misma Doña Urraca arrodillada, juntas, elevadas, y extendidas las manos, repitiéndose su nombre, cuyas letras comienzan sobre su cabeza, y baxan por delante, extendiéndose casi tanto como la figura." 


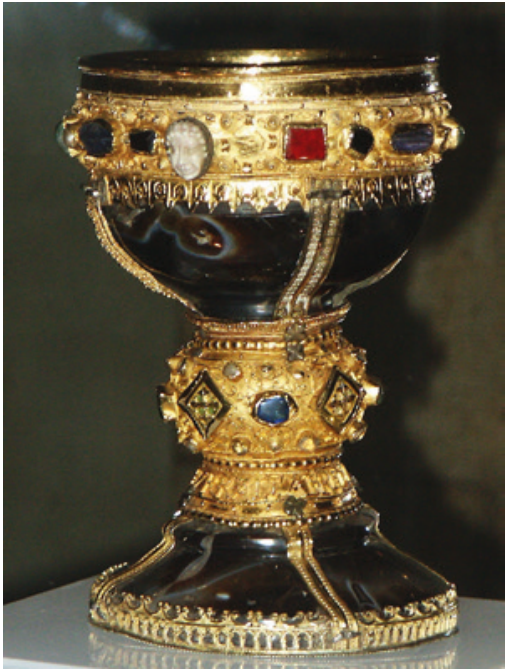

FIGURE 2.5

Chalice of Urraca, ca. 1067-1101 (Museo de la Real Colegiata de San Isidoro de León).

PHOTO: THERESE MARTIN

vestments of the clergy with gold, silver, and precious stones." ${ }^{61}$ In the early thirteenth century, it is the infanta and her parents to whom Lucas of Tuy, in his Liber miraculorum beatissimi Isidori, gives credit for the establishment of the treasury: “... the treasures that were in the church of the confessor San Isidoro, which is in León; these had been gathered there by King Fernando and Queen Sancha and their daughter the venerable Urraca ${ }^{62}$ for the beauty of the

61 "ac omni vite sue tempore in ornandis auro argentoue pretiosisque gemmis sacris altaribus sacerdotalibusque vestimentis desideratum exercitium peregit," ed. Justo Pérez de Urbel and Atilano González Ruiz-Zorrilla, Historia Silense. Edición crítica e introducción (Madrid: Consejo Superior de Investigaciones Científicas, 1959), 122-123. This chronicle is now more commonly referred to as the Legionensis. See the special issue Historia legionensis (llamada silensis). Écriture de l'histoire, e-Spania 14 (Dec. 2012), http://journals.openedition.org/e-spania/21568. For a Spanish edition, see Manuel Gómez-Moreno, Introducción a la Historia Silense con versión castellana de la misma y de la crónica de Sampiro (Madrid: Junta para Ampliación de Estudios e Investigaciones Científicas, Centro de Estudios Históricos, 1921), LXxi. For an English edition, see Simon Barton and Richard Fletcher, The World of El Cid: Chronicles of the Spanish Reconquest (Manchester: Manchester University Press, 20oo), 9-64.

62 It is also worth noting, however, that in the Chronicon mundi, which Lucas of Tuy completed after the miracles and which he wrote for a royal rather than ecclesiastical audience, he ascribes the treasures to kings Fernando and Alfonso VI, eliminating all reference to the contributions of Sancha and Urraca. Here also Alfonso el Batallador is cast as the despoiler of the church, following the counsel of his cousin Henry of Burgundy, Count of Portugal, together with his wife, Queen Urraca. See Lucas Tudensis. Chronicon Mundi, ed. Emma Falque Rey, Corpus Christianorum Continuatio Mediaevalis, 74 (Turnhout: Brepols, 2003), 4:72. See also Beatriz Antón, 
divine cult and the honor of San Isidoro."63 Lucas's mention of the treasure occurs in reference to the moment when Queen Urraca allowed her husband Alfonso I of Aragón to plunder the church of San Isidoro in order to pay his troops. Because of its importance for the evolving history of the treasury, the full section bears quoting:

And since all of Queen Urraca's treasures had been completely exhausted and King Pedro [sic, Alfonso el Batallador] could not pay his soldiers what he had promised them, through sacrilegious counsel he advised the queen that, in order to pay the salaries of the soldiers, he should take by force the treasures that were in the church of the confessor Saint Isidore, which is in León; these had been gathered there by King Fernando and Queen Sancha and their daughter the venerable Urraca for the beauty of the divine cult and the honor of Saint Isidore. To this diabolical counsel and persuasion Queen Urraca gave consent, and those abominable invaders, irreverently putting aside both fear of God and the abject shame of man, with the queen's permission, pestiferously entered the church and looted the treasures consecrated to God. Those workers of hell, satellites of the devil, infernal hammerers broke everything into pieces, reserving it to their lords' and their own wanton and villainous uses: crosses of Our Lord, chalices with Christ's consecrated body and blood, images of Holy Mary Mother of God and of other saints, candelabra, thuribles, plates [fialas], crowns, caskets with holy relics, aquamaniles, and many other objects [ynsignia] from that

"Argumentos medievales como fuente de los Emblemata centum regio politica (Madrid, 1653) de J. de Solórzano: la muerte de la Reina Urraca de Castilla," in IV Congresso Internacional de Latim Medieval Hispânico, Lisboa, 12-15 de Outubro de 2005, Actas, ed. Aires A. Nascimento and Paulo F. Alberto (Lisbon: Centro de Estudos Clásicos, 2006), 167-181, esp. $175^{-177}$.

63 Biblioteca de la Real Colegiata de San Isidoro, ms. 61, cap. xxv: "thesauri qui erant in ecclesia beati Ysidori confessoris, que sita est in Legione, quos ibi rex Fredenandus et Sanctia regina necnon et uenerabilis Urraca utriusque filia ad diuini cultus decorem et beati Ysidori honorem aggregauerant." I am grateful to Patrick Henriet for providing me the corrected Latin text from the critical edition he currently has underway. The only published edition of the miracles is Julio Pérez Llamazares, ed., Milagros de San Isidoro (León [1947]; Universidad de León, facs. ed. 1992), which is itself a reedition of the first Romance translation of 1525 by Juan de Robles. For Lucas de Tuy, see the studies in Cahiers de Linguistique et de Civilisation Hispanique Médiévales 24 (2001): Patrick Henriet, "Sanctissima patria: Points et themes communs aux trois oeuvres de Lucas de Tuy," 249-277; Peter Linehan, "Dates and Doubts about Don Lucas," 201-217. 
church, and all were of gold and silver, with precious stones of diverse colors and great brilliance, and with this those most impudent dogs in their ignorance were satiated. ${ }^{64}$

Lucas records a terrible event in the history of the monastery at which he spent most of his ecclesiastical career before going on to become bishop of Tuy. In fact, this incident was so traumatic that it is still the story told at San Isidoro today. How, then, can we explain the fact that there continues to be a magnificent treasury at the Leonese monastery? Here Lucas of Tuy also provides an answer, but this chapter of the Miracles, by contrast with the former, has not been assimilated into common lore: Lucas names Queen Urraca and her eldest daughter Sancha as the restorers of San Isidoro. In reference to the queen, the chronicler's tone throughout both the Miracles and his Chronicon mundi was extremely disapproving, which lends weight to this single instance in which he spoke highly of her actions:

Queen Urraca, in order to expiate the aforementioned great crime [of having permitted her husband to despoil the church], together with her most prudent daughter Sancha, who from childhood affirmed that she had taken Saint Isidore as her spouse, refusing a husband's carnal coupling, with great zeal they desired to restore to the church of the holy confessor that which had been removed. In addition the queen repeatedly proceeded to have many relics of saints zealously gathered from diverse parts of the world, and she had them placed with honor in caskets of silver and ivory. With royal munificence she conferred many properties

64 Biblioteca de la Real Colegiata de San Isidoro, ms. 61, cap. xxv: “... cum omnes thesauri regine Urrache essent exausti penitus, et rex Petrus quod promiserat suis militibus unde tribueret non haberet, consilio ductus sacrilego suggesit regine ut thesauri qui erant in ecclesia beati Ysidori confessoris, que sita est in Legione, quos ibi rex Fredenandus et Sanctia regina necnon et uenerabilis Urraca utriusque filia ad diuini cultus decorem et beati Ysidori honorem aggregauerant, inuaderet ad stipendia militibus conferenda. Diabolicis cuius suasionibus assensum prebuit regina Urraca, et orriferi inuassores, Dei timore postposito et hominum irreuerenter abiecta uerecundia, regine accepta licencia, pestilenter ingrediuntur ecclesiam et thesauros consecratos Deo diripiunt, et fabri gehennales, satellites diaboli, malleatores inferni, dominicas cruces, calices Christi corpore et sanguine consecratos, sancte Dei genitricis Marie et aliorum sanctorum ymagines, candelabra, turibula, fialas, coronas, sanctarum reliquiarum arcellas, aquemanilia et alia multa ynsignia eiusden ecclesie que omnia erant aurea uel argentea, in quibus erant lapides preciosi diuerso colore fulgentes, canes inpudentissimi, saturitatem nescientes, uniuersa dissoluunt et confringunt, dominorum suorum et suis lasciuis usibus et sceleribus reseruantes." 
on the church, and during her lifetime she had a burial place prepared for herself in that church with her forebears. ${ }^{65}$

So, can we believe either of these two accounts by Lucas of Tuy? I would argue that we can; in fact, we can believe both of them. It would not be at all surprising that a ransacking of the church took place around 1110-1112 during the tumultuous commencement of Queen Urraca's reign. And perhaps she even allowed it, taking for granted her right as ruler to make use of-or to bestow on another - the objects within her dynastic church, these gifts to San Isidoro given by members of her family. ${ }^{66}$ Although not all the earlier treasury would have been taken, it seems probable that some of the most highly valuable gold pieces were appropriated and that some reliquaries were profaned. As noted above, Urraca made a very generous donation to San Isidoro in 1117 , and as Lucas himself would recount in the Chronicon mundi, she was indeed buried with honor at San Isidoro. Thus, his reference in the miracle to the conferring of properties on San Isidoro by Urraca and the preparation for her burial there are both verifiable facts.

Why, then, should the chronicler's identification of Urraca as the donor of "caskets of silver and ivory" to the same institution be dismissed out of hand, especially given the continued presence of twelfth-century objects of the type Lucas recognizes as having originated in "diverse parts of the world"? Despite Urraca's infamous reputation for requisitioning liturgical metalworks to pay her troops, this stigma was well deserved only in the first part of her reign. ${ }^{67} \mathrm{In}$ the contribution by Julie Harris to this volume, the author contextualizes two

65 Cap. XXX: "Regina ectiam Urraca, tanti supradicti piaculi gratia expiandi, vna cum prudentissima filia sua Santia, que beatum Ysidorum sponsum suum a puericia testabatur, carnali sponso renuens copulari, sumo studio que fuerant ab ecclesia sancti confessoris ablata restaurare cupiebant, et toto cognamine his exsequendis dabant operam eficacem. Preterea regina sepe facta multorum sanctorum reliquias de diuersis mundi partibus fecit studiossisime congregari, et in capssis argenteis et eburneis fecit honorifice collocari. Eidem ecclesie regali munificencia multa contulit predia, et in ipsa ecclesia cum patribus suis sibi fecit parari, dum adhuc viueret, sepulturam."

66 I am grateful to Jitske Jasperse for this suggestion. For the ties between gift-giving and violence, see Andrew Cowell, The Medieval Warrior Aristocracy: Gifts, Violence, Performance and the Sacred (Cambridge: D. S. Brewer, 2007).

67 Pascual Martínez Sopena, "La circulation des objets en temps de guerre. Les années de la reine Urraca (León et Castille, vers 1110-1130)," in Objets sous contraintes: Circulation des richesses et valeur des choses au Moyen Âge, ed. Laurent Feller and Ana Rodríguez (Paris: Publications de la Sorbonne, 2013), 257-282. Of the twenty-two cases studied by the author, sixteen occurred before 1117, none that year, and only six from 1118 until the queen's death in 1126. If a similar assessment has been carried out for the reigns of Alfonso VI or Alfonso VII, I am unfamiliar with it. 
moments in which the queen requisitioned church goods as disposable wealth in the presence of members of the Jewish community. ${ }^{68}$ But Urraca is also recorded by her contemporaries for donating relics and gifts to ecclesiastical institutions, such as the head of Saint James to the Cathedral of Santiago de Compostela.

When [Queen Urraca] realized that Bishop Mauricio had brought the head of Saint James from Jerusalem and that it was in San Zoilo [Carrión de los Condes], she herself took it from there together with the rest of the relics and brought it to León, placing it at San Isidoro. And thus she made a gift of such a great treasure to the bishop of Santiago, that is: the head of Saint James, a fragment of the sepulcher of the Lord, a bone of Saint Stephen, and other relics with a silver container. ${ }^{69}$

The gifts to San Isidoro at the behest of women from four generations of the ruling dynasty bespeak an interest in the highest quality materials to honor the saint while representing the donors, but we also catch glimpses of additional elements that made these gifts so exalted, like the antiquity of the sardonyx cups put together to create the infanta's chalice, or the purple of the Byzantine silk in the "1063 charter." In the queen's case, Lucas recognizes the importance of possessions from discernibly distant shores when he portrays her ordering the gathering of relics from diverse lands. Such trappings of far-off lands bespeak an ambitious ruler, eager to extend her dominion and to make her aspirations visible at the heart of her family's dynastic church. This type of appreciable geography, however, could also be used to evoke local prestige, as it does for a coherent group of ivories from León.

\section{5 \\ The Treasury in the Fourteenth Century: Evidence of the Beatitudes Casket}

Although an analysis of the Leonese ivory workshop is beyond the purview of the present article, one object originating from this center serves here as a

68 See Chpt. 8, Julie A. Harris, "Jews, Real and Imagined, at San Isidoro and Beyond."

69 Historia Compostellana, ed. Emma Falque Rey, Corpus Christianorum Continuatio Mediaevalis 70 (Turnhout: Brepols, 1988), Book I, 112, 267-8: "Que ut nouit caput beati Iacobi, quod M. episcopus Iherosolimis attulerat, in ecclesia sancti Zoyli esse, ipsamet illud cum ceteris reliquiis abhinc abstraxit et asportauit Legionem collocans in ecclesia sancti Isidori. Tantum igitur thesaurum, scilicet apud beati Iacobi et frustum Dominici sepulcri et quoddam os sancti Stephani ceterasque reliquias cum uase argenteo contulit predicto beati Iacobi episcopo." 
case study for examining assumptions about the larger group and their place at San Isidoro. Looking closely at a single work in the light of finely tuned scientific scrutiny offers evidence alongside archival work for a greater understanding of the treasury as a whole. If, as John Williams has argued, the Cross of Fernando and Sancha represents the first product of a newly established ivory workshop in León, ${ }^{70}$ this masterpiece stands as a precedent for a series of objects created through the late eleventh and early twelfth centuries. Among the most important pieces assigned to the royally sponsored ivory workshop founded by Fernando and Sancha are two elaborate reliquaries composed of multiple plaques of ivory. The Casket of Saints John the Baptist and Pelayo, which has lost the golden ornamentation that once covered the wooden core, is still at San Isidoro; its exquisite silk lining is addressed and illustrated in the present volume in the studies by Ana Cabrera and María Judith Feliciano. The second reliquary, densely covered by a profusion of ivory, is today held by the Museo Arqueológico Nacional, one of the objects requisitioned in 1869 (Figure 2.6; inv. no. 52092). Called the Beatitudes Casket, this box serves as a metaphor for our larger research project due to its visual mixing of cultures and to the new history of its place in the medieval treasury that is the result of technical analysis together with historical and art historical research carried out by members of the Treasury project.

The name by which the reliquary is now known comes from the casket's unconventional imagery of winged figures paired with lively, gesticulating personifications of the Beatitudes, identified by abbreviated inscriptions from the Sermon on the Mount in Matthew 5:3-12 (Figure 2.7). The casket's current configuration, however, cannot be original: as scholars have long recognized, some of the Beatitudes are missing; the ivories on the fourth side are unrelated to the other three; and the plaques were secured to the surface of the wooden core by nails rather than inset within the framework. Yet in the historiography, this reliquary is consistently associated with the donation by Fernando and Sancha, providing an apparently firm date for the style of the plaques bearing Christian imagery. ${ }^{71}$

The three sides with figural imagery have received sustained iconographic analysis by scholars, foremost among them Julie Harris; she situates these images within the context of the Hispanic liturgy, which was being replaced by

70 John Williams, "León: The Iconography of a Capital," in Cultures of Power: Lordship, Status, and Process in Twelfth-Century Europe, ed. Thomas N. Bisson (Philadelphia: University of Pennsylvania Press, 1995), 231-258.

71 See recently, with extensive previous bibliography, Noemi Álvarez da Silva, "The Beatitudes Casket. A New Reconstructive Hypothesis," Imago Temporis. Medium Aevum 8 (2014): 109-134. 


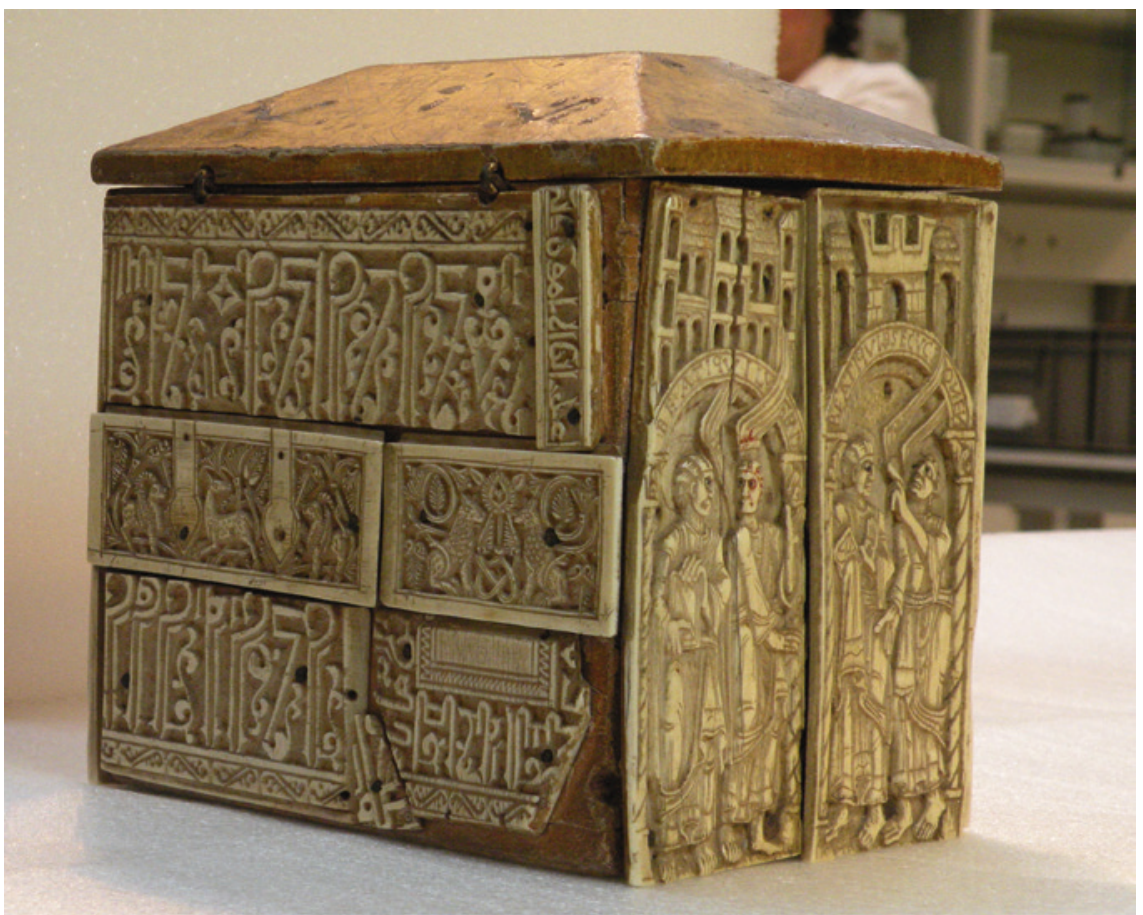

FIGURE 2.6 Beatitudes Casket, oblique view, ivories from the late eleventh century (?) on fourteenth-century wooden box (Madrid, Museo Arqueológico Nacional, Inv. No. 52092). See also Fig. 1.1.

PHOTO: THERESE MARTIN

the Roman rite at the end of the eleventh century. ${ }^{72}$ And yet, the casket's fourth side, which bears a series of smaller ivory fragments with animal and foliate forms as well as Arabic inscriptions, has yet to be fully understood, much less integrated into a study of the object as a whole. These fragmentary plaques have generally been separated from studies of the existing casket because they were clearly manufactured in Islamic lands and hence belong to the category of "Islamic art" (Figure 2.8). But their integration with the Beatitudes plaques on this casket carries deep resonance for the history of the treasury of San Isidoro more broadly as they further attest to the continued importance of objects from exotic lands.

72 Julie A. Harris, “The Beatitudes Casket in Madrid's Museo Arqueológico: Its Iconography in Context," Zeitschrift für Kunstgeschichte 53/1 (1990):134-139. See also María Concepción Cosmen, "La Arqueta de las Bienaventuranzas: fuentes iconográficas," De Arte 1 (2002): 21-30. 


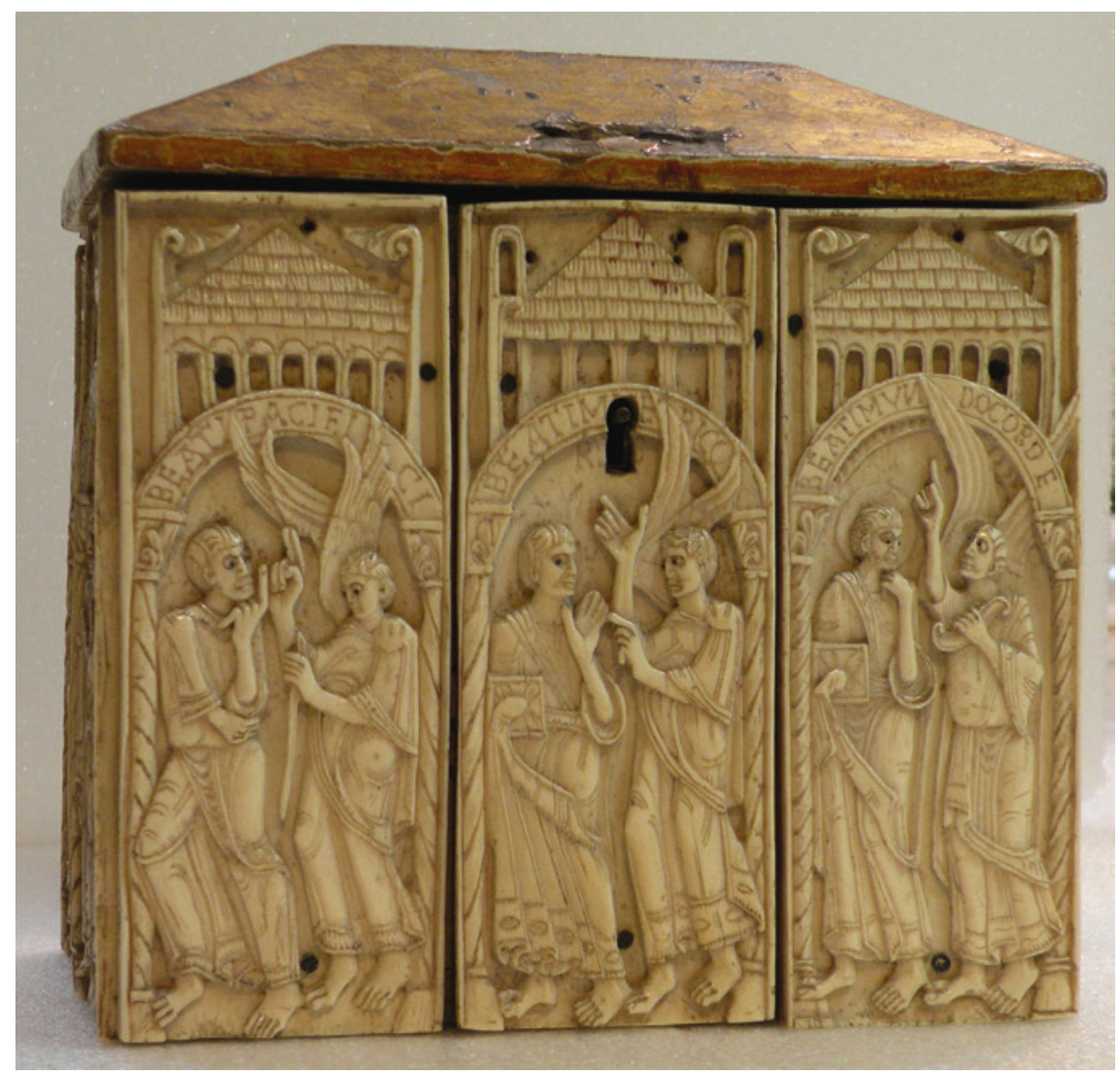

FIGURE 2.7 Beatitudes Casket, Christian imagery, late eleventh century? (Madrid, Museo Arqueológico Nacional, Inv. No. 52092). See also Fig. 1.1. PHOTO: THERESE MARTIN

In order to understand the complicated history of the fourth side of the Beatitudes casket, together with its relevance for the later history of the treasury, the epigraphic expertise of María Antonia Martínez Núñez is essential. She is currently deciphering the partial Arabic inscriptions and her work has already begun to shed light on the pieces' complicated chronologies. The smallest inscription, appearing in the upper right corner of the box, belongs stylistically with the two centrally placed plaques that display animals in a paradisiacal landscape, despite their different orientations. It is the only inscription that had previously been understood, giving us the name "Ismail, son of al-Ma'mūn, 


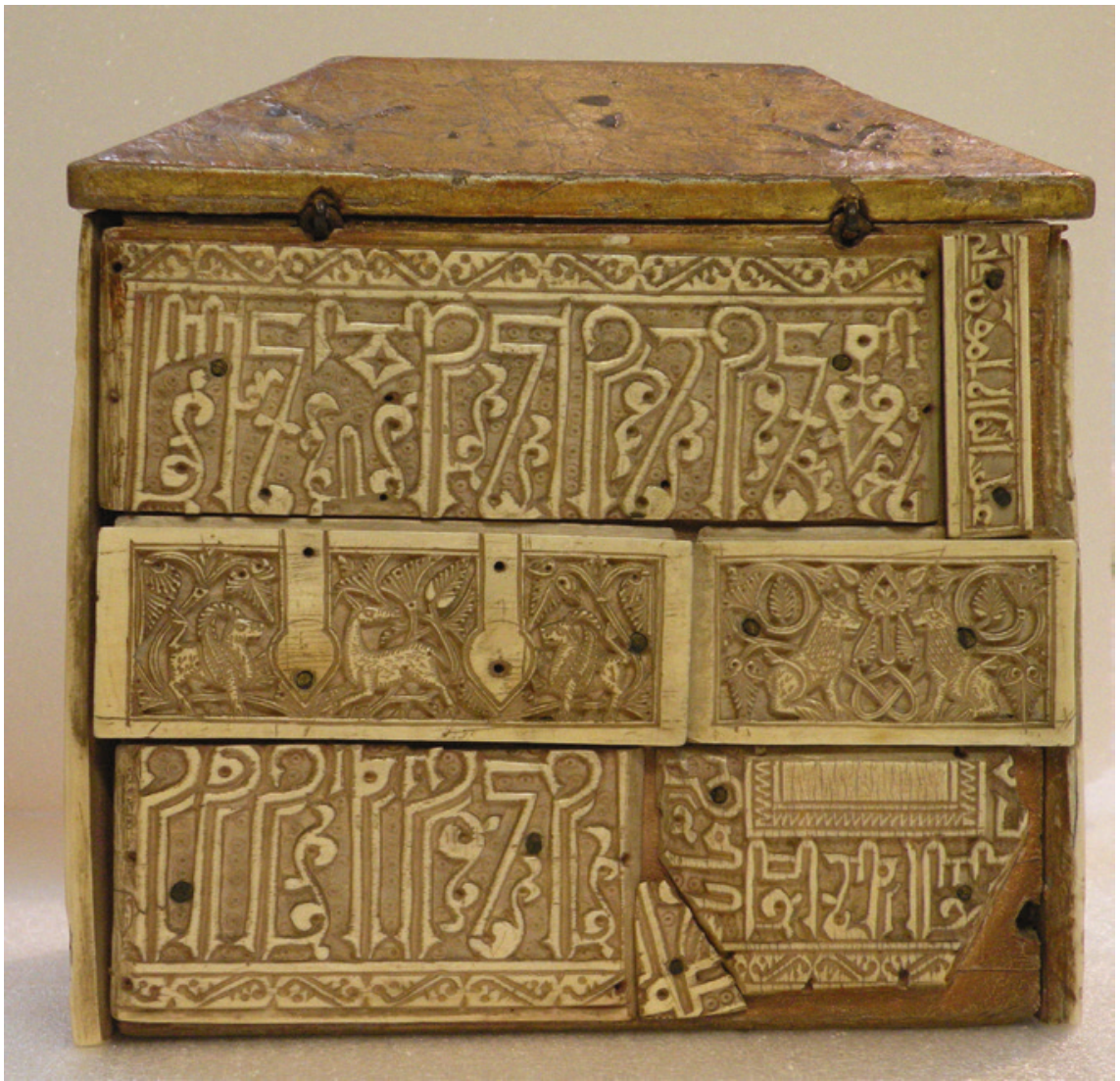

FIGURE 2.8 Beatitudes Casket, Arabic plaques, late eleventh century? (Madrid, Museo Arqueológico Nacional, Inv. No.52092). See also Fig. 1.1.

PHOTO: THERESE MARTIN

he of the two glories."73 Al-Ma'mūn was the ruler of the taifa kingdom of Toledo from 1043 to 1075 . The three fragments must once have belonged to a single luxury box made for the emir's son; this object, therefore, can be easily contextualized through both style and inscription with similar objects produced in Cuenca around the year $1050 .{ }^{74}$

The rest of the pieces on the fourth side of the Beatitudes Casket, forming the upper and lower bands, apparently all come from another single box. The

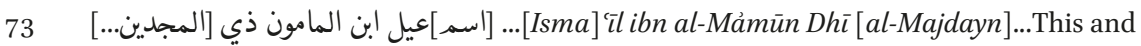
the following transcriptions and translations are all by María Antonia Martínez Núñez, epigrapher extraordinaire. I am most grateful for her collaboration and for allowing me to present her preliminary results here. Previous partial readings are summarized by Ángel Galán y Galindo, Marfiles medievales del Islam (Córdoba: Publicaciones Obra Social y Cultural Cajasur, 2005), 1:393-395; 2:82-84.

74 See recently Noelia Silva Santa-Cruz, La eboraria anda lusí del califato omeya a la Granada nazarí, BAR International Series, vol. 2522 (Oxford: Archaeopress, 2013). 
scale of the script indicates a casket larger than the one that can be reconstructed from the Cuenca fragments, but these are much more complicated to set within a specific historical context. If fact, the second set of inscriptions has often been taken for pseudo-script rather than the highly ornamental but true Arabic that they are. Now, thanks to Martínez Núñez's reading, we can begin to situate the plaques in their original place and time. From this second ivory box, two sides have been preserved on the Beatitudes Casket, installed upside-down in order to take deliberate advantage of the vegetal border as a framing device for the new setting. In this particularly ornate Kufic, Martínez Núñez recognizes graphic features that are present in some Andalusi inscriptions from the eleventh century. She has been able to discern the following parts of phrases:

in the upper plaque, "with glory was;"75

below, as two separate words, "joy" and "blessing;"76

in the smallest fragment, "happiness;"

and finally lower right, "for its owner. The gratitude ..."78

These last references are to an unnamed owner, and they would have been located on the lid of the original ivory box. On the basis of the types of script on the plaques, Martínez Núñez confirms that two different workshops produced the taifa-era boxes reused in the making of the Beatitudes Casket. One was certainly from the well-known Cuenca workshop, but in her opinion the variety of Kufic on the other box is only comparable to the highly ornamental epigraphic lettering on buildings in Toledo under the Banū Dī l-Nūn, who ruled 1032-1085, or in Zaragoza during the time of the Banū Hūd (1039-1110). ${ }^{79}$ Further research is needed to pin down these ivory fragments to their source. What is clear is that the full complement of ivories on the Beatitudes Casket derives from three different objects made in León, Cuenca, and Toledo or Zaragoza with dates that would appear to coalesce around the latter part of the eleventh century.

\footnotetext{
$75 \quad$ (اسياد (؟) bi-cizz kāna.

$76 \quad$ (su)rūr and baraka.

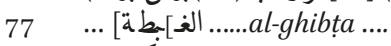

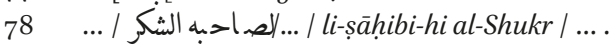

79 On the larger context of the taifa kingdoms that arose after the end of the caliphate in 1031, see David Wasserstein, The Rise and Fall of the Party-Kings: Politics and Society in Islamic Spain, 1002-1086 (Princeton: Princeton University Press, 1985); Pierre Guichard and Bruna Soravia, Les royaumes de taifas: apogée culturel et déclin politique des émirats andalous du XIe siècle (Paris: Geuthner, 2007).
} 


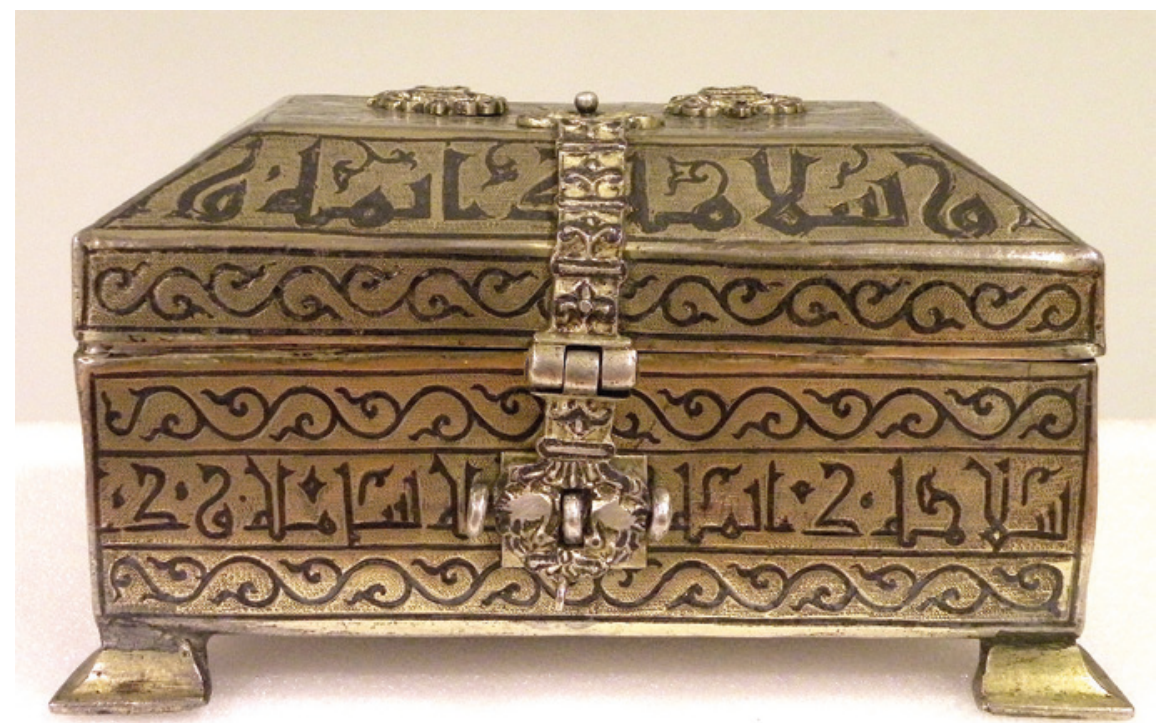

FIGURE 2.9 Silver Andalusi casket, turn of the twelfth century? (Madrid, Museo Arqueológico Nacional, Inv. No. 50867).

PHOTO: THERESE MARTIN

The phrasing on the larger taifa box is typical of the sorts of generic beneficent wishes for an unspecified recipient that appear on luxury goods of Islamic manufacture made on spec, such as a silver niello Andalusi box from San Isidoro, now at the Museo Arqueológico Nacional (Figure 2.9; inv. no. 50867). Susana Calvo Capilla dates the object to the early twelfth century; if she is correct, this chronology situates it as one more work from the treasury at San Isidoro that would not have been part of the 1063 donation. ${ }^{80}$ According to Stefano Carboni, the inscription reads:

8o Susana Calvo Capilla, "Arqueta," in Maravillas de la España medieval. Tesoro sagrado y monarquía, ed. Isidro Bango Torviso (Valladolid: Junta de Castilla y León, 2001), 1:113. However, in a March 2018 personal communication, Julian Raby stated that he does not think that the casket was made well into the twelfth century, nor that it was it necessarily produced before 1063. He locates this box in the late eleventh century on epigraphic forms. For the larger context of Andalusi metalwork, see Julian Raby, "The Inscriptions on the Pisa Griffin and the Mari-Cha Lion: From Banal Blessings to Indices of Origin," in The Pisa Griffin and the Mari-Cha Lion. Metalwork, Art, and Technology in the Medieval Islamicate Mediterranean, ed. Anna Contadini (Pisa: Pacini Editore, 2018), 305-36o + addendum to n.73. I am grateful to Julian for sharing his ideas about Andalusi metalwork with me. 
Lid: Entire blessing and continuous well-being and complete health and perfect bounty and $[\ldots]$

Body: Entire blessing from God and continuous well-being [and] complete [heal]th and perfect favor and perpetual happiness and [...] wellbeing to its owner. ${ }^{81}$

Objects with this type of non-individualized dedication are evidence of elite production due to the costliness of their materials, but they were not made under official state control, as was the case with the caliphal ivory workshop that flourished at the Cordoban palace of Madinnat al-Zahrä' from around 96o through the early eleventh century. ${ }^{82}$

While ongoing research on the ivory plaques of the Beatitudes Casket adds nuanced chronology and geography for the object as a whole, the inner wooden core too has provided dramatic new evidence for the history of this piece. Before technical analysis, it was assumed that the wood was either from the eleventh century, to fit with the donation by Fernando and Sancha, or from the nineteenth century, when the object entered the museum in Madrid. Instead, carbon-14 analysis revealed that the wood dates firmly to the fourteenth century, with a $95 \%$ probability that it falls within the years CE $1295-1415 .{ }^{83}$ This date was completely unexpected. Instead of focusing on the years around either 1063 or 1869 , it became necessary to consider what the fourteenth century had to offer in the context of San Isidoro's treasury. A further surprise awaited our delighted discovery: documentary evidence from 1331 at the archive at San Isidoro accords perfectly with the carbon-14 date. Indeed, in looking at the late medieval context of the treasury, the Beatitudes Casket emerges as a part of a larger story about lay benefactors' donations to ecclesiastical institutions, along with the evolving interests of religious communities. Based on technical analysis and the following written source, I would argue that the casket must have taken its present form at this key moment in the institution's fourteenthcentury history.

81 Stefano Carboni, “Casket," in The Art of Medieval Spain, AD 500-1200, exh. cat. (New York: Metropolitan Museum of Art, 1993), 98. He dates the casket to the first half of the eleventh century.

82 For an excellent study that brings scholarship on the caliphal ivories up to date, see Glaire D. Anderson and Mariam Rosser-Owen, "Great Ladies and Noble Daughters: Ivories and Women in the Umayyad Court at Córdoba," in Pearls on a String: Art in the Age of Great Islamic Empires, ed. Amy Landau (Seattle: University of Washington Press, 2015), 28-51.

83 Beta Analytic no. 442369, 59 о в $+/-3$; in the calibrated result two moments within this range stand out: 1310-136o and 1385-1405. My thanks go to Mónica Ruiz for carrying out the delicate task of sampling the wood. 
In order to encourage donations to San Isidoro for reconstruction needed on the church building, an itemization was undertaken in 1331 of all the relics and indulgences possessed by the monastery. ${ }^{84}$ This same charter formalized the benefits of becoming a contributing member of the institution's confraternity, under the Pendón, or Pennant, of San Isidoro. ${ }^{85}$ The editor of the sacred inventory, Santiago Domínguez Sánchez, notes that the document was written in ocher ink with many red majuscules, in a hand that imitates the Gothic script used for privileges, without being particularly elegant. ${ }^{86}$ The opening line of this fund-raising effort directs the document, "To all the faithful of God, whether clerics or knights, and good men and good ladies of whatever places in which this letter might be seen ..." ${ }^{87}$ The list of major relics naturally begins with Isidore himself, and it includes a ten-line summation of the many cures and other types of miracles wrought by the saint since his relics were translated from Sevilla to León. Isidoro is followed in importance by Vincent, along with his sisters Sabina and Cristeta. These four holy figures are highlighted because, as stated, their full bodies rest at San Isidoro, whereas the other holy remains were partial, summarily noted as relics from, bones of, dress of, and so on.

84 Santiago Domínguez Sánchez, Patrimonio cultural de San Isidoro de León. Documentos del siglo XIV (León: Universidad de León, 1994), 178-181, Archivo de San Isidoro de León, no. 103. This 1331 inventory was repeated in the last decade of the fourteenth century, dated 1393 with additions shortly thereafter, stating that this time it was done in the presence of Alfonso Fernández de Cuevas and Gonzalo Ruiz de Villalón, scribes and notaries to the king. There are some minor changes in the list of relics-Malachi, companion of Bernard, becomes Matthias - but on the whole it is the same list of relics and indulgences. See Domínguez Sánchez, Patrimonio cultural de San Isidoro de León. Documentos del siglo XIV, 494-497, Archivo de San Isidoro de León, no. 104.

85 Gregoria Cavero Domínguez, "La instrumentalización de la ayuda isidoriana en la Reconquista: La Cofradía del Pendón de Baeza en San Isidoro de León," Homenaje a la profesora María Isabel Falcón, special issue, Aragón en la Edad Media 19 (2006): 113-124, in which the author proposes that the Pendón was made in conjunction with the 1331 inventory. See also Alberto Montaner Frutos, "El Pendón de San Isidoro o de Baeza: sustento legendario y constitución emblemática," Emblemata 15 (2009): 29-70 at 32: "el Pendón de San Isidoro se elaboró en el período comprendido entre dicho año de 1331 y el de 1360, aunque más cerca del segundo que del primero, como un efecto secundario de la restauración de dicha cofradía." In the opinion of Etelvina Fernández González, "Héroes y arquetipos en la iconografía medieval," Cuadernos del CEMYR 1 (1993): 13-52, at 36, the Pennant "no es anterior al siglo XIV."

86 Domínguez Sánchez, Patrimonio cultural de San Isidoro de León. Documentos del siglo XIV, $178-181$.

87 "A todos los fieles de Dios, así clérigos commo caualleros et ommes bonos et bonas duennas de qualesquier lugares que esta carta vierdes ..." For examples of similar efforts at other sites, see W.H. Vroom, Financing Cathedral Building in the Middle Ages: The Generosity of the Faithful (Amsterdam: Amsterdam University Press, 2010), 219-229. 
The remaining relics are briefly enumerated, from multiple scenes of Christ's Passion to Mary's milk, along with bones from Anna, Peter, Paul, James, Andrew, Bartholomew, Matthew; from the head of John the Baptist; the relatives Laurence and Vincent; bones from the Massacre of the Innocents and "a good amount" (bona quantía) of their blood as well; gold and myrrh and incense offered by the Three Kings; bones from the martyrs Claudius, Lupercius, and Victorius; vestments and bones from Martino, Nicholas, Augustine, Thomas of Canterbury, Iustus and Pastor, the prophet Samuel; the oak of Mamre under which Abraham dwelt; ${ }^{88}$ Catherine and the oil that flowed from under her tomb on Mount Sinai; an unnamed "cardinal who was martyred in Constantinople;" Malachi, bishop and companion of Bernard; bones and vestments from Margaret, Speratus, Marina, Agnes, Dorothy, and Engracia; and water that flowed before the altar of San Isidoro. The scribe ends his impressive list of Christological relics and martyrs' remains with the catch-all phrase, "and there is still more, other bodies of saints that are not recounted here."

Following the multiplicity of relics, the charter's next major selling point is that San Isidoro is the site of royal burial, "thirty-two kings and queens and infantes," along with many counts and rich men who offered their bodies and souls to the blessed confessor San Isidoro, understanding that through his prayer they could gain a place in Paradise. And then comes the scribe's request: because of the church's great antiquity, it is in danger, and the canons cannot undertake a major renovation of the building without the help of good men and good women. Therefore, the canons "looked into the coffer of the treasury (catemos la archa del tesoro) and found the indulgences and the pardons that the Holy Apostolic Fathers in Rome and cardinals and archbishops and bishops gave and bestowed on those who did well for this monastery, that is: Pope Innocent, one year and 100 days of pardon ..." and an extensive etcetera of the indulgences granted by many ecclesiastical authorities. After noting the length of time in each indulgence, our scribe totals it all up: 5 oo years from popes and other major players, and 500 forty-day periods from the archbishops and bishops. He then explains the origins of the confraternity following the miraculous appearance by San Isidoro, who rode into the battle of Baeza to save Emperor Alfonso VII. The charter concludes: "And so we order that all those men and those women who join this confraternity and give an amount for construction work or for a laborer, we will receive them as siblings in the said holy confraternity and in the said pardons," explaining the prayers, vigils,

88 For a comparison with other Old Testament relics, see Chpt. 8 in this volume, Julie A. Harris, "Jews, Real and Imagined, at San Isidoro and Beyond." 
and sacrifices, songs, processions, and ringing of bells that would be done on the donors' behalf, especially if they leave their best clothes to San Isidoro upon their deaths. This moment, in which the institution's holy treasures were inventoried and publicized, would have been the perfect opportunity to make use of the precious remains of old ivory caskets for a new display of relics.

Reading this 1331 document together with the results of the carbon-14 testing, I argue that it is most likely that the Beatitudes Casket was put together in the fourteenth century when the canons of San Isidoro decided to publicize their relics and indulgences in order to seek new donations. In creating the Beatitudes Casket as we see it today, the canons of San Isidoro gave new life to the remnants of three cherished boxes-two of Islamic provenance and one with Christian imagery - whose broken fragments of valuable ivory had been carefully stored away in the past. Joining together local Leonese production with Arabic script that by this time bespoke both distant past and far-removed lands, the canons refreshed and updated their own history. What is more, they assembled a regenerated piece based on a common sumptuous material rather than a coherent iconography to enhance the prestige of the institution's many relics and to frame their newly public display. Carrying an aura of antiquity, even sacrality from their renewed use in contact with relics, the disparate ivory pieces reconstructed on a single casket demonstrated a continued alliance with monastery's past patrons, both royal and saintly.

Yet, as essential as the 1331 document has been in establishing the historical context for the fashioning of the casket, from an art historical perspective the narrative is sadly wanting, for the canons of San Isidoro were not interested in inventorying the containers holding all their treasured relics. Regarding the physical repositories, they tell us only that "among the other things, there are also eight small caskets filled with relics and with holy bodies which, as we learned from our ancestors, they never dared to open." ${ }^{\prime 9}$ Curiously missing from the lineup of saints detailed above are the remains of Pelayo, who, together with John the Baptist, was one of the site's original patrons before the arrival of Isidore. Was Pelayo's prestige so diminished by the fourteenth century that there was no point in even mentioning him? Or, given that Pelayo had been the patron of the female half of the mixed community, might it be that his relics left León in 1148 with the nuns when they were removed to Carbajal? In either case, the silence surrounding Pelayo in the 1331 inventory serves as

89 Domínguez Sánchez, Patrimonio cultural de San Isidoro de León. Documentos del siglo XIV, 178-181: "Et entre las otras cosas remaneçen ocho arquetas lenas de reliquias et de cuerpos santos que segundo aprendimos de nuestros antescesores que nunca fueron hosados de los [abrir]." 
a useful reminder that interests and emphases shift over time in a long-lived institution like San Isidoro.

The articles in this volume center on a single Iberian monument in order to highlight issues of wider relevance for research concerning medieval treasuries. Foremost among these is the necessity of bringing different types of evidence to bear in order to put long-held assumptions to the test. Our studies demonstrate that collaboration among scholars with a range of interdisciplinary methods and approaches—-textual, visual, and technical — successfully opens new windows onto the past. In taking San Isidoro de León as a case study, we apply a healthy dose of skepticism about accepting the written record at face value while carefully mining documents, chronicles, and hagiographies to extract historical facts from medieval narratives. Written sources are further evaluated against art historical and scientific evidence to determine how much weight should be accorded to each in the final balance. For San Isidoro, a critical reading of the "1063 charter" contributes to an understanding of royal aspirations, first those evident in the treasury's foundation by Fernando and Sancha, and later through its restoration in the twelfth century by Queen Urraca. The founders sought to establish a long-lasting legacy in León, which was upheld by their granddaughter as she fought to rule independently over the largest Christian kingdom in Iberia. I accept the truth behind the tales told by Lucas of Tuy, both that the beleaguered queen allowed the pillaging of her family's church and later that, in an ambitious public performance of rulership, Urraca reestablished its treasury, possibly with some of the twelfthcentury ivory and silver caskets that can still be seen today. It seems likely that members of her lineage, especially the infanta Sancha and Alfonso VII, would have continued the dynastic tradition of offering precious goods to San Isidoro, as they must have done when the church was re-consecrated in $1149 .{ }^{90}$ Yet the preponderance of treasury objects dated to the early twelfth century or before suggests that this practice waned throughout that century, with the casket from Limoges marking an end to the era of large-scale royal sponsorship.

The history of an institution does not halt, however, simply because the rulers' attention turns elsewhere. For San Isidoro's treasury, the first-ever

9o For this event, documented by a surviving inscription, see Martin, Queen as King, 153-154, fig. 106 . 
application of technical analyses to a range of objects has led to new questions and altogether unexpected answers. Carbon-14 testing pushed our investigation further and, together with archival research, revealed an underappreciated yet key moment in the history of the monument. The fourteenth century was shown to be a time of reaching out to non-elite donors, men and women who were encouraged to join the confraternity with an eye to the hereafter. Through the construction of the reliquary now known as the Beatitudes Casket, precious ivory fragments from San Isidoro's past played a role in ensuring the institution's survival into the future.

As this volume makes clear, the Iberian material is ripe for incorporation into comparative studies of medieval treasuries. Caskets of silver, ivory, bone, or antler made their way to León from Scandinavia and al-Andalus, from across the Pyrenees or beyond the Mediterranean, while textiles came from as far east as Central Asia. Each transfer of a luxury object embodies a long-distance connection; each object in León indicates that some form of contact existed, suggesting a future avenue of research at the objects' points of origin as well as their destination. Aspirational rulership, through such networks and relationships, are made manifest in this treasury, where the malleable meanings of individual pieces were completed by their new dispositions within the larger collection. At San Isidoro, geography resonates through both surviving works and written sources for the four generations of women who were the driving force behind the treasury's development in the eleventh and twelfth centuries. Whether women played such central roles at treasuries outside León is another question ripe for future comparative research.

\section{Acknowledgments}

Republication of this study in the present volume was supported by the Index of Medieval Art (Princeton University) and The Medieval Iberian Treasury in Context: Collections, Connections, and Representations on the Peninsula and Beyond (National Research Challenge Grant, Spanish Ministry of Science, Innovation, and Universities, AEI/FEDER, RTI2018-o98615-B-Ioo, 2019-2022, PI Therese Martin). 